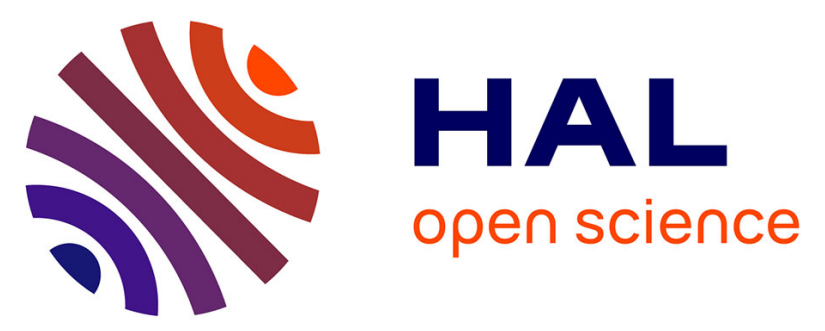

\title{
Headwater valley response to climate and land use changes during the Little Ice Age in the Massif Central (Yzeron basin, France)
}

Hugo Delile, Laurent Schmitt, Nicolas Jacob-Rousseau, Loïc Grosprêtre, Grégoire Privolt, Frank Preusser

\section{To cite this version:}

Hugo Delile, Laurent Schmitt, Nicolas Jacob-Rousseau, Loïc Grosprêtre, Grégoire Privolt, et al.. Headwater valley response to climate and land use changes during the Little Ice Age in the Massif Central (Yzeron basin, France). Geomorphology, 2016, 257, pp.179-197. 10.1016/j.geomorph.2016.01.010 . halshs-01302648

\section{HAL Id: halshs-01302648 \\ https://shs.hal.science/halshs-01302648}

Submitted on 14 Apr 2016

HAL is a multi-disciplinary open access archive for the deposit and dissemination of scientific research documents, whether they are published or not. The documents may come from teaching and research institutions in France or abroad, or from public or private research centers.
L'archive ouverte pluridisciplinaire HAL, est destinée au dépôt et à la diffusion de documents scientifiques de niveau recherche, publiés ou non, émanant des établissements d'enseignement et de recherche français ou étrangers, des laboratoires publics ou privés. 


\title{
Headwater valley response to climate and land use changes during the Little Ice Age in the Massif Central (Yzeron basin, France)
}

\author{
Hugo Delile a,b,*, Laurent Schmitt ${ }^{c}$, Nicolas Jacob-Rousseau ${ }^{a}$, Loïc Grosprêtre ${ }^{\mathrm{d}}$, \\ Grégoire Privolt ${ }^{\mathrm{d}}$, Frank Preusser ${ }^{\mathrm{e}}$ \\ a University Lumière Lyon 2, UMR 5133 CNRS Archéorient, 69365 Lyon, France \\ b Department of Archaeology, University of Southampton, Avenue Campus, Southampton SO17 1BF, United Kingdom \\ c University of Strasbourg, UMR LIVE 7362 CNRS-ENGEES, 67083 Strasbourg, France \\ ' University Lumière Lyon 2, CNRS UMR 5600, 69676 Bron, France \\ e University of Freiburg, Institute of Earth and Environmental Sciences, Albertstr. 23b, 79104 Freiburg, Germany
}

\section{A R T I C L E I N F O}

\section{Article history:}

Received 27 August 2015

Received in revised form 15 January 2016

Accepted 19 January 2016

Available online 21 January 2016

\section{Keywords:}

Little Ice Age

Headwater valley bottom deposits

Aggradation-incision cycle

OSL and radiocarbon dating

Landscape history

Massif Central

\begin{abstract}
A B S T R A C T
The geomorphological response of valley bottoms in eastern France to climatic fluctuations of the Little Ice Age (LIA) was investigated using sedimentological analysis together with optically stimulated luminescence (OSL) and radiocarbon dating. Diachronic mapping of land use since the beginning of the nineteenth century was also carried out. Since A.D. 1500, the valley bottoms experienced three cycles of aggradation and subsequent incision, each characterized by paired periods of high and low detritic activity. While the impact of human activity on the aggradation of the alluvial plain is observed, the vertical dynamics of the valley bottom deposits seemingly were also linked to the hydroclimatic fluctuations during the LIA. The sensitivity to these fluctuations was increased by human activity at the scale of the basin. Variations of the winter North Atlantic Oscillation (NAO) and solar activity from the last five centuries correlate with wet and cold phases during which valley bottoms accumulated, and dry and warm phases during which the streams incised into the valley floors. This fluvial sensitivity to the meteorological conditions induced temporal variations in sedimentary supply originating from either direct input from remnants of periglacial alluvial sheets or local rocky outcrops and/or from indirect input from the erosion of alluvial and colluvial deposits. These two components, combined with the sheet runoff over the ploughlands, express the complex coupling between hillslopes and valley bottoms in the headwater catchments. This caused a cascade-shaped transit of the sediments characterized by alternating phases of storage and removal.
\end{abstract}

(c) 2016 Elsevier B.V. All rights reserved.

\section{Introduction}

The Little Ice Age (LIA) is the last pronounced period of climate cooling, which was defined by historians and Earth Sciences as comprising stricto sensu A.D. 1550-1850 (Lamb, 1977; Grove, 1988; Acot, 2005). This episode is marked by a significant advance of Northern Hemisphere glaciers owing to long and severe winters and relatively cool and wet summers. These climatic conditions are particularly well documented by historical climatology studies through the evolution of the grape harvest dates (Dufour, 1870; Angot, 1883; Le Roy Ladurie, 1967; Chuine et al., 2004; Meier et al., 2007; Garnier et al., 2011; Daux, 2012) and the comparison of iconographic representations of glaciers (Le Roy Ladurie, 1967; Nussbaumer et al., 2012; Zumbühl and Nussbaumer, 2012). Some work has also been conducted on the geomorphological

* Corresponding author at: University Lumière Lyon 2, UMR 5133 CNRS Archéorient, 69365 Lyon, France.

E-mail address: hdelile@gmail.com (H. Delile). evolution of rivers and valley bottoms since the Medieval Climate Optimum (Bravard, 1989, 2000; Rumsby and Macklin, 1996; Gob, 2005; Gob et al., 2008; Jacob-Rousseau and Astrade, 2010, 2014; Macklin et al., 2012;; Notebaert et al., 2014; Lespez et al., 2015). For example, Bravard $(1989,2000)$ has shown that the braided pattern of most rivers of the French Alps appeared after the increase of sediment production during the LIA, but sometimes with a significant time delay. This trend was not found in the Mediterranean area and the Massif Central, in part because of fewer studies on geomorphological adjustments of watercourses during the LIA (Gob et al., 2008; Cubizolle, 2009). In this regard, Jacob (2003) concluded that southeastern Massif Central rivers experienced some phases of short hydrosedimentary fluctuations, i.e., aggradation of their alluvial floor during periods of high sediment supply followed by incision rather than a bed metamorphosis like the Alpine rivers. Moreover, the manifestation of the LIA does not appear to be homogenous across the Mediterranean region (Berger et al., 2010) because low temperatures were associated with drought in the eastern part as in the Iberian Peninsula (Carozza et al., 2014); such an 
evolution could have decreased sediment production. Finally, Macklin et al. $(1994,1995)$ reported a negative feedback in semiarid Mediterranean mountainous landscapes, where the wetter climate could have increased the vegetation cover and then decreased hillslope coarse material supply.

In the present work, we focus on the internal secular rhythmicity of the LIA. Notably, the LIA was not a period of continuously disturbed climatic conditions over three centuries, but characterized by quiet phases interrupting the general trend. Indeed, some authors have shown that this period was not characterized by disturbed climatic conditions but known as an alternance of crises and lulls. It has been pointed out first in the southern Alps (Douguedroit, 1979; Jorda, 1980; Neboit, 1983; Gautier, 1992; Pichard, 1995; Miramont and Guilbert, 1997) then in the Languedoc (Berger et al., 2010) and the southeastern Massif Central (Jacob, 2003; Gob, 2005; Gob et al., 2008; Astrade et al., 2011). The fluvial sensitivity to these fluctuations may depend on the size of the basin. The timing of adjustments can also vary because the downstream progradation of debris from headwater streams to lower valleys presumably requires a relatively long time (Bravard, 1989, 1993; Gob et al., 2008; Astrade et al., 2011; Jacob-Rousseau and Astrade, 2014). According to Gob et al. (2008), the three main sedimentation phases of rivers and deltas occurred exactly at the same time as the principal torrential crises that affected the western Mediterranean during the LIA (see discussion below). Conversely, these episodes are interspersed with two multidecennial phases of severe droughts during the second half of the seventeenth and early eighteenth centuries and during the early nineteenth century (Carozza et al., 2014). Nevertheless, Wilhelm et al. (2012) observed a time delay in flood frequencies during the last four centuries between the southern Alps and the Mediterranean coast of Spain and the Cévennes area. According to these authors, these differences could be explained by two northwestern Mediterranean atmospheric circulation paths affecting the area with a frequency of 50 to 150 years.

This article presents a case study from the Yzeron basin based on optically stimulated luminescence (OSL) and radiocarbon dating of valley bottom deposits in order to understand the relative influence of climate and human occupation during the LIA. The first aim of this paper is to describe the internal secular rhythmicity of the LIA and its geomorphic implications as observed in valley bottom deposits. In light of what has been stated above, the geographical situation (in the northeastern part of the Massif Central) and the size of the studied hydrosystems (headwater basins) should argue for an early and sensitive recording of the internal LIA hydroclimatic fluctuations.

In line with our previous work (Preusser et al., 2011), the second aim is to assess the relative influence of land use evolution in the sedimentary filling of valley bottoms. Our initial hypothesis was that the valley floor in which current incision occurs has been developed during widespread agricultural activity (mainly ploughlands) and that incision could have been triggered by a later decline in sediment supply from cultivated hillslopes. However, Preusser et al. (2011) also highlighted that such small basins show high sensitivity to climate and land use variations. In order to answer the question regarding the forcing factors of sediment dynamics (hillslope soil erosion, valley bottom deposition, remobilization of valley bottom sediments), we require (i) a diachronic mapping of land use since at least the nineteenth century in the four studied subcatchments and (ii) a chronostratigraphic model of these valley bottom deposits. On the latter point, a review of different dating methods has been provided by Lang et al. (1999) showing that radiocarbon dating and dendrochronology are problematic for such sediments, as these methods rely on the dating of reworked material (i.e., wood). As a consequence, such dating approaches may overestimate the true age of sediment accumulation (e.g., Lang and Hönscheidt, 1999; Huckleberry and Rittenour, 2014). Luminescence methods are now frequently used for the dating of colluvial and alluvial sediments, as recently reviewed by Fuchs and Lang (2009).

\section{Study area}

The Yzeron basin $\left(147 \mathrm{~km}^{2}\right)$ is a right-side tributary of the Rhône River located near the city of Lyon (Fig. 1). From west to east, in the

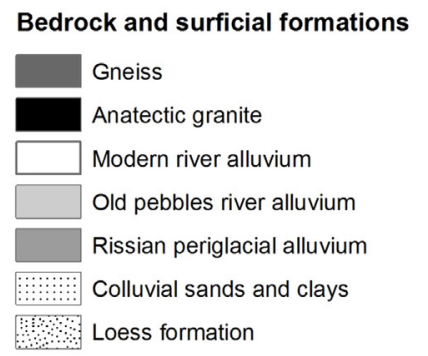

Hydrography and topography
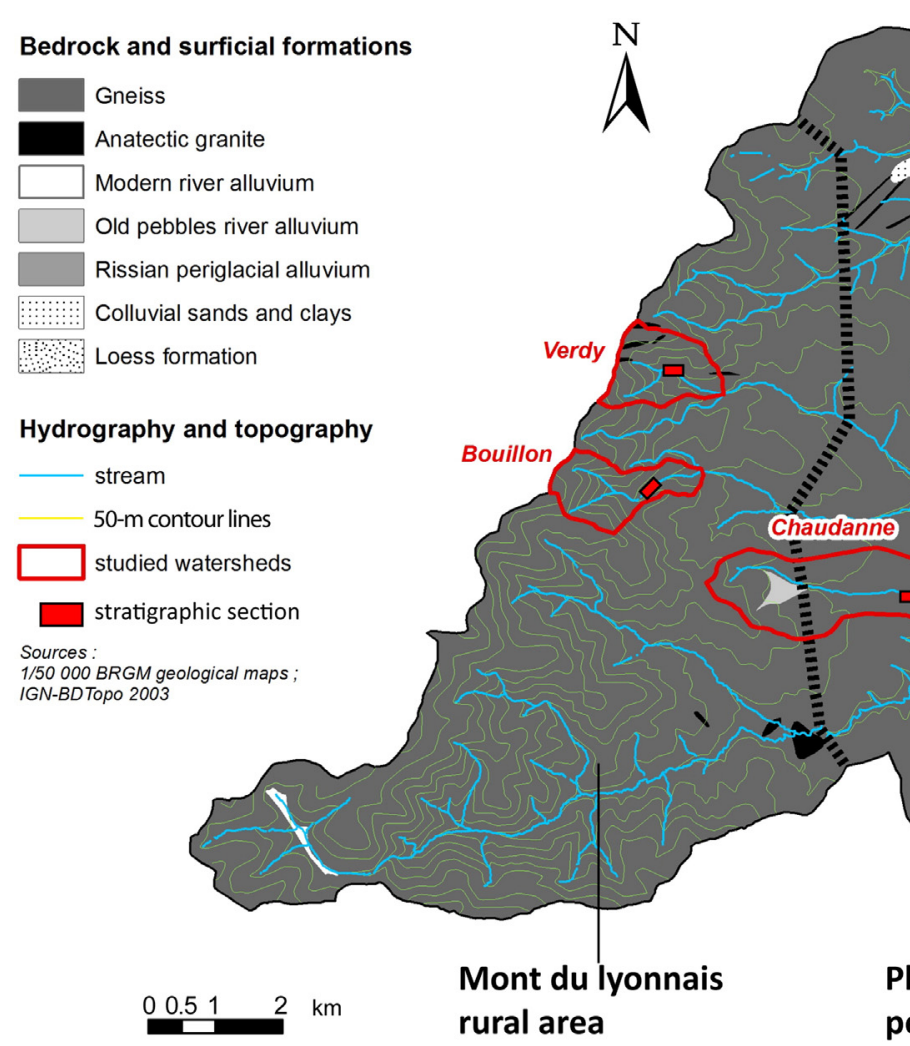

FRANCE

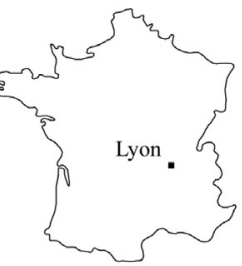


downstream direction, the basin drains a subdued, degraded granitic and gneissic mountain (Monts du Lyonnais, a mostly rural area; altitude from 900 to $400 \mathrm{~m}$ ), a gneissic and partly granitic plateau (Plateau Lyonnais, a mostly peri-urban area in the Lyon neighborhoods; altitude from 400 to $250 \mathrm{~m}$ ), and some inherited, mostly alpine, fluvial and glacial deposits (part of the urban area of Lyon; altitude from 250 to $165 \mathrm{~m}$ ). In the last area, the hydrographic network is scarce because of the high permeability of the inherited geological features. Some discontinuous loess covers exist in the eastern part of the basin. Valley bottoms are relatively large and incised into the plateau (Schmitt et al., 2006).

In the Monts du Lyonnais and the Plateau Lyonnais, hillslopes are generally covered by sandy regolith with a typical thickness of about $1 \mathrm{~m}$ (Mandier, 1984). This regolith is highly sensitive to soil erosion in the absence of permanent vegetation. The hydrological regime is pluvial oceanic with a Mediterranean influence in the autumn. The high hydrological variability caused by this last influence is strengthened by the low permeability of the substratum and the thinness of the superficial permeable geological features (Chocat, 1997).

Despite the current lack of available palaeoenvironmental data during the last millennia on the Yzeron catchment, we can obtain some insight into past dynamics thanks to the regional studies carried out on the Rhône and the eastern Massif Central. In the Forez Mountains (east of the Monts du Lyonnais), it was during the first Iron Age that the main phase of the highland land-clearing (above $1300 \mathrm{~m}$ ) occurred (Cubizolle, 2009). Then the transition between the Tene and the GalloRoman period is marked by continued deforestation and the intensification of agricultural practices. This is the beginning of a mixed agropastoral economy in the Massif Central (Miras et al., 2004). The Gallo-Roman period is part of a long dry period (from the fourth century B.C. to the fourth century A.D.), which was punctuated by repeated flooding episodes of the Rhône River in Lyon and Vienna from the first century B.C. to the second century A.D. (Bravard and Petit, 2000; Bravard and Salvador, 2009). At Vaise, the first centuries of our era are characterized by a general deterioration of the slopes on which colluviation, torrential activity, and mudslides caused soil erosion. These slope processes are linked to anthropogenic pressures (total disappearance of the forest, cultivation, anthropogenic fires), urbanization, and the increased frequency of rainfall events (Bertran et al., 1998). This morphogenic crisis seems especially important at the end of the Gallo-Roman period when sites were abandoned. In the context of human settlement at that time, the Plateau Lyonnais is considered to be a densely populated space. Evidence for this human occupation is manifold, including tegulae, potsherds, ceramics, remains of large villas, tanks, pipes, walls, ovens, etc. (Lorcin and Houssel, 2008).

Palaeoenvironmental research in the Yzeron basin was initiated from problems with current management of river morphodynamics. Significant channel incision is observed for one-third of the headwater streams, and it is characterized by an average lowering of bed channels of $2 \mathrm{~m}$ and a maximum of $6 \mathrm{~m}$. We know from public records and dendrochronological analyses of riparian trees that incision began mostly between about A.D. 1970 and 1990. The most significant incision occurred in peri-urban subbasins where urban inflow (UI) and/or combined sewer overflow (CSO) increase peak flow intensity and flood frequency (Grosprêtre, 2011; Schmitt et al., 2011; Navratil et al., 2013). Incision also occurs in the upland rural area, however, where CSO is absent and UI is much less common. This raises the question of the origin of channel degradation in the rural area. Incision has exposed several stratigraphic sections of which four are the subject of this study (Fig. 1). These are located in four subcatchments of the Yzeron basin that are representative of the variety of geographical settings of this catchment: the Bouillon $\left(1.2 \mathrm{~km}^{2}\right)$ and Verdy $\left(0.8 \mathrm{~km}^{2}\right)$ watersheds in the Monts du Lyonnais, and the Chaudanne $\left(3.7 \mathrm{~km}^{2}\right)$ and PrésMouchettes $\left(0.4 \mathrm{~km}^{2}\right)$ watercourses in the Plateau Lyonnais (Fig. 1).

More extensive field work, such as coring of the floodplains, was not considered relevant to this study as our main question concerns the characterization and dating of incised sediments only, in order to predict the occurrence of and mitigate current incisions.

\section{Materials and methods}

\subsection{Sedimentological analyses}

We sampled stratigraphic sections to analyze grain size distributions (Delile et al., 2014, for details of the pretreatment) in order to understand the nature of the valley bottom filling and the hydrosedimentary processes. While the sediment fraction $>1.6 \mathrm{~mm}$ was sieved using several sizes of sieves, the fraction $<1.6 \mathrm{~mm}$ was measured by a Malvern Mastersizer 2000 laser granulometer. The interpretation of granulometric curves was based on the CM diagram (also called the Passega image), which uses the median $\left(D_{50}\right)$ and the coarsest percentile $\left(D_{99}\right)$ to determine depositional and transport processes (Salomon et al., 2012; Delile et al., 2015a,b). Magnetic susceptibility (MS) was measured directly on the sections to detect variations in ferromagnetic mineral contents in sediments, mostly Mn- and Fe-oxides, hydroxides, and oxyhydroxides (Dearing, 1999). In fluvial environments, MS reflects the terrigenous flux derived from fluvial hydrodynamics in deltaic (Salomon et al., 2012; Delile, 2014; Delile et al., 2014, 2015a,b) and mountainous areas (e.g., Arnaud et al., 2005, for the Rhône River activity). Moreover, these minerals can be introduced by pedogenetic processes and thereby can be transported, then accumulated in alluvium or colluvium, consecutively to soil erosion events (Dearing et al., 1996; Vannière et al., 2000). Magnetic susceptibility was measured three times using a Bartington MS2E1 (Dearing, 1999).

Loss on ignition (LOI) was measured in the muffle furnace from $10 \mathrm{~g}$ sediment heated $16 \mathrm{~h}$ at $375{ }^{\circ} \mathrm{C}$. LOI gives a crude measure of the sediment's organic content, which tends to increase when fluvial activity is reduced (Arnaud-Fassetta, 2008).

\subsection{Radiocarbon dating}

Radiocarbon ages for charcoal and vegetal matter were obtained utilizing the linear accelerator at Saclay. Two more radiocarbon ages (tree trunks) were measured at the University of Laval (Table 1). Uncertainties on raw radiocarbon ages BP are reported at the $95 \%$ confidence level $(2 \sigma)$. The measured ${ }^{14} \mathrm{C}(\mathrm{BP})$ ages were converted into B.C.-A.D. calibrated dates by Clam software (Blaauw, 2010) using the continental calibration curve of Reimer et al. (2013).

It is important to state that many taphonomic biases are likely to complicate the interpretation of these radiocarbon dates. We distinguish between two types of disturbance related to post-depositional processes: those intervening at the scale of the charcoal in soils and those relating to the nature of the deposits. In the first case, burial conditions, mixing, and fragmentation of charcoals in soils by biotic (e.g., earthworms) and abiotic (e.g., cryoturbation) agents are likely to modify the charcoals' original stratigraphic positions (Carcaillet and Talon, 1996; Théry-Parisot et al., 2010; Chrzazvez et al., 2014). Therefore, the dating of soil horizons can be difficult. Moreover, it is possible to date charcoals derived from the same tree and obtain dates differing by up to several centuries, depending on the species of tree dated. That is, charcoals derived from the sapwood and the heartwood of a tree stump will not provide the same dates. Finally, the charcoals could be removed many centuries after their formation, which could make the deposit old. In the second case, taphonomic biases can occur, especially in river valleys where human occupation sites can be buried under several meters of colluvium and/or alluvium caused by hydrological disturbances (Berger, 2011). Hence, because archeological remains preserved in sediments are heavily dependent on river palaeodynamics and the settlement's position in the floodplains (Brown, 1997), knowledge of taphonomic contexts (Holocene colluvial/alluvial deposits, Pleistocene alluvial fans, etc.) and the use of taphonomic corrections can change 
Table 1

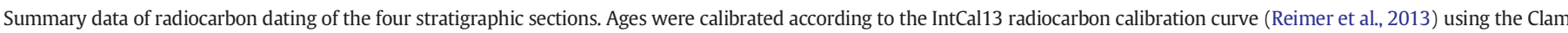
software (Blaauw, 2010).

\begin{tabular}{|c|c|c|c|c|c|c|}
\hline Section & Sample code & Depth $(\mathrm{cm})$ & Laboratory code & Material & ${ }^{14} \mathrm{C}$ age (BP) & Calendar age (BC-AD) $(2 \sigma)$ \\
\hline Chaudanne & CHAU 40 & 40 & Lyon-6276 (SacA-16,670) & Charcoal & $320 \pm 30$ & 1485-1645 AD \\
\hline Chaudanne & CHAU 165 & 165 & Lyon-6279 (SacA-16,673) & Vegetal matter & $305 \pm 30$ & 1490-1650 AD \\
\hline Chaudanne & CHAU 185 & 185 & Lyon-6280 (SacA-16,674) & Charcoal & $285 \pm 30$ & 1510-1665 AD \\
\hline Chaudanne & CHAU 230 & 230 & Lyon-6281 (SacA-16,675) & Charcoal & $305 \pm 30$ & 1490-1650 AD \\
\hline Chaudanne & CHAU 285 & 285 & Lyon-6282 (SacA-16,676) & Charcoal & $380 \pm 30$ & 1445-1630 AD \\
\hline Chaudanne & CHAU-AMONT & 220 & ULA-1140 & Tree stump & $285 \pm 20$ & $1520-1655$ AD \\
\hline Chaudanne & CHAU-DROITE & $310-350$ & ULA-1141 & Tree stump & $355 \pm 20$ & $1460-1630 \mathrm{AD}$ \\
\hline Bouillon & BOU 85 & 85 & Lyon-6272 (SacA-16,666) & Charcoal & $390 \pm 30$ & $1440-1630 \mathrm{AD}$ \\
\hline Bouillon & BOU 120 & 120 & Lyon-6274 (SacA-16,668) & Charcoal & $1235 \pm 30$ & $685-880 \mathrm{AD}$ \\
\hline Bouillon & BOU 135 & 135 & Lyon-6273 (SacA-16,667) & Charcoal & $365 \pm 30$ & 1450-1635 AD \\
\hline Bouillon & BOU 195 & 195 & Lyon-6270 (SacA-16,664) & Charcoal & $905 \pm 30$ & 1035-1205 AD \\
\hline Bouillon & BOU 230 & 230 & Lyon-6271 (SacA-20,265) & Charcoal & $875 \pm 30$ & 1045-1225 AD \\
\hline Prés-Mouchettes & PM 95-110 & $95-110$ & Lyon-6268 (SacA-16,662) & Charcoal & $900 \pm 30$ & $1040-1210 \mathrm{AD}$ \\
\hline Prés-Mouchettes & PM 135-145 & $135-145$ & Lyon-6269 (SacA-16,663) & Charcoal & $1640 \pm 30$ & $335-535 \mathrm{AD}$ \\
\hline Verdy & VER 55 & 55 & Lyon-6266 (SacA-16,660) & Charcoal & $595 \pm 30$ & $1300-1410 \mathrm{AD}$ \\
\hline Verdy & VER 80 & 80 & Lyon-6267 (SacA-16,661) & Charcoal & $190 \pm 30$ & 1650-1865 AD \\
\hline
\end{tabular}

our perception of the history of human occupation (Verhagen and Berger, 2001; Berger, 2011).

\subsection{OSL dating}

Altogether, 20 samples have been dated using OSL, of which seven have been already presented in Preusser et al. (2011) where methodological aspects are discussed in detail. The following discussion will summarize the key issues. Material for determination of equivalent dose $\left(D_{e}\right)$ was dried and sieved (see Table 2 for used grain size) and subsequently treated with $\mathrm{HCl}, \mathrm{H}_{2} \mathrm{O}_{2}$, and $\mathrm{Na}$-Oxalate to remove carbonates and organic matter and to disperse clay particles. The quartz fraction was isolated using heavy liquids (LST fast flow with densities of 2.70 and $2.58 \mathrm{~g} \mathrm{~cm}^{-3}$ ) and etched with $40 \% \mathrm{HF}$ for $1 \mathrm{~h}$, followed by treatment with $\mathrm{HCl}$ to dissolve fluoride precipitates. Sample PM4 had too little sand to allow application of the above procedure. Here, the fraction 4$11 \mu \mathrm{m}$ was enriched by settling and etched in $\mathrm{H}_{2} \mathrm{SiF}_{6}$ for one week to remove feldspar.

All OSL measurements were made using a Risø DA20 TL/OSL reader. Samples were exposed to IR stimulation prior to all measurements, and aliquots that produced any substantial signal response to this stimulation were considered to be contaminated by feldspar and excluded from further analyses. The OSL was recorded during a 60s stimulation by blue diodes at $125^{\circ} \mathrm{C}$ using a Hoya U340 detection filter. The OSL signal from most of the small $(2 \mathrm{~mm})$ aliquots is rather bright and dominated by the fast component (Preusser et al., 2011). The first $0.2 \mathrm{~s}$ of the signal have been used for analyses. A modified single aliquot regenerative dose (SAR) (Murray and Wintle, 2000) was used for $D_{e}$ determination. A series of standard performance tests was carried out (Wintle and Murray, 2006), and accordingly samples were preheated at $230^{\circ} \mathrm{C}$ for $10 \mathrm{~s}$ prior to all OSL measurements. All samples show evidence for the presence of partial bleaching. Preusser et al. (2011) compared different approaches to extract the population of aliquots representing wellbleached grains; we use the minimum age model of Preusser et al. (2007), which has proven to be most robust. This approach cannot be applied to the fine-grained sample PM4 as the large number of grains on the sample carrier will mask the effect of partial bleaching. Hence, the OSL age of this sample will only represent a maximum estimate and it is discarded from further discussion.

Determination of dose rate elements used a low-level, highresolution gamma spectrometer (Preusser and Kasper, 2001). Following the approach described by Zander et al. (2007) and Preusser and Degering (2007), we did not observe evidence for radioactive disequilibrium in the uranium decay chain. Average water content was estimated based on the sediment moisture measured in the lab, including some uncertainty to account for possible past changes in the

Table 2

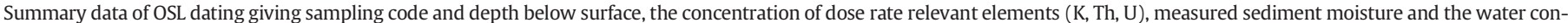
tent (W) used for calculations of dose rate (D), together with the number of replicate measurements (n) und grain size used for equivalent dose (De) determination.

\begin{tabular}{|c|c|c|c|c|c|c|c|c|c|c|c|c|}
\hline Sample & $\begin{array}{l}\text { Depth } \\
(\mathrm{cm})\end{array}$ & $\begin{array}{l}\mathrm{K} \\
(\%)\end{array}$ & $\begin{array}{l}\text { Th } \\
(\mathrm{ppm})\end{array}$ & $\begin{array}{l}\mathrm{U} \\
(\mathrm{ppm})\end{array}$ & $\begin{array}{l}\text { Mois. } \\
(\%)\end{array}$ & $\begin{array}{l}W \\
(\%)\end{array}$ & $\begin{array}{l}\mathrm{D} \\
\left(\mathrm{mGy} \mathrm{a} \mathrm{a}^{-1}\right)\end{array}$ & $\mathrm{n}$ & $\begin{array}{l}\text { Grain size } \\
(\mu \mathrm{m})\end{array}$ & $\begin{array}{l}\mathrm{D}_{\mathrm{e}} \\
(\mathrm{Gy})\end{array}$ & $\begin{array}{l}\text { Age } \\
\text { (a) }\end{array}$ & $\begin{array}{l}\text { Age } \\
\mathrm{AD}\end{array}$ \\
\hline CHAU7 & 26 & $3.24 \pm 0.03$ & $11.94 \pm 0.29$ & $3.47 \pm 0.12$ & 19.4 & $20 \pm 5$ & $4.06 \pm 0.44$ & 51 & $100-150$ & $0.33 \pm 0.02$ & $79 \pm 7$ & 1920-1935 \\
\hline CHAU6 & 60 & $3.76 \pm 0.04$ & $10.69 \pm 0.42$ & $3.13 \pm 0.02$ & 20.1 & $20 \pm 5$ & $4.37 \pm 0.33$ & 50 & $150-200$ & $0.90 \pm 0.05$ & $206 \pm 17$ & $1785-1820$ \\
\hline CHAU5 & 105 & $3.82 \pm 0.03$ & $14.07 \pm 0.31$ & $4.09 \pm 0.06$ & 22.9 & $20 \pm 5$ & $4.78 \pm 0.24$ & 40 & $150-200$ & $1.67 \pm 0.17$ & $350 \pm 41$ & $1615-1700$ \\
\hline CHAU4 & 150 & $4.15 \pm 0.03$ & $5.59 \pm 0.09$ & $1.76 \pm 0.02$ & 5.9 & $10 \pm 5$ & $4.52 \pm 0.33$ & 45 & $150-200$ & $1.91 \pm 0.18$ & $424 \pm 35$ & $1550-1620$ \\
\hline CHAU3 & 210 & $3.84 \pm 0.03$ & $11.67 \pm 0.26$ & $3.32 \pm 0.09$ & 16.8 & $20 \pm 5$ & $4.43 \pm 0.33$ & 44 & $150-200$ & $0.77 \pm 0.04$ & $172 \pm 14$ & $1820-1850$ \\
\hline CHAU2 & 252 & $3.78 \pm 0.03$ & $11.24 \pm 0.26$ & $3.42 \pm 0.05$ & 14.3 & $20 \pm 5$ & $4.43 \pm 0.42$ & 43 & $150-200$ & $0.48 \pm 0.05$ & $109 \pm 13$ & 1885-1910 \\
\hline CHAU1 & 295 & $3.90 \pm 0.03$ & $12.23 \pm 0.53$ & $3.61 \pm 0.07$ & - & $20 \pm 5$ & $4.86 \pm 0.43$ & 43 & $150-200$ & $0.71 \pm 0.04$ & $154 \pm 13$ & 1840-1865 \\
\hline BOU6 & 20 & $4.07 \pm 0.03$ & $12.05 \pm 0.30$ & $4.38 \pm 0.06$ & 19.4 & $20 \pm 5$ & $4.67 \pm 0.40$ & 45 & $150-200$ & $0.17 \pm 0.01$ & $35 \pm 3$ & 1970-1975 \\
\hline BOU2 & 65 & $4.12 \pm 0.09$ & $7.27 \pm 0.17$ & $2.63 \pm 0.04$ & 9.8 & $15 \pm 5$ & $4.55 \pm 0.30$ & 48 & $150-200$ & $1.04 \pm 0.04$ & $228 \pm 17$ & 1765-1795 \\
\hline BOU5 & 75 & $4.20 \pm 0.03$ & $8.84 \pm 0.16$ & $3.26 \pm 0.03$ & 20.2 & $20 \pm 5$ & $4.53 \pm 0.21$ & 46 & $250-300$ & $0.68 \pm 0.05$ & $152 \pm 14$ & $1840-1870$ \\
\hline BOU4 & 160 & $4.02 \pm 0.04$ & $8.63 \pm 0.15$ & $4.41 \pm 0.07$ & 18.2 & $20 \pm 5$ & $4.78 \pm 0.30$ & 46 & $100-150$ & $2.46 \pm 0.19$ & $517 \pm 51$ & $1440-1540$ \\
\hline BOU3 & 220 & $4.17 \pm 0.04$ & $6.29 \pm 0.26$ & $2.91 \pm 0.08$ & 11.0 & $15 \pm 5$ & $4.55 \pm 0.27$ & 46 & $150-200$ & $1.57 \pm 0.08$ & $345 \pm 27$ & $1635-1690$ \\
\hline BOU1 & 205 & $4.16 \pm 0.09$ & $4.99 \pm 0.07$ & $2.15 \pm 0.04$ & 8.7 & $15 \pm 5$ & $4.26 \pm 0.26$ & 40 & $150-250$ & $1.54 \pm 0.09$ & $360 \pm 30$ & $1620-1680$ \\
\hline PM4 & 22 & $2.65 \pm 0.02$ & $16.22 \pm 0.20$ & $4.03 \pm 0.05$ & 24.3 & $25 \pm 5$ & $5.03 \pm 0.48$ & 5 & $4-11$ & $2.97 \pm 0.10$ & $588 \pm 61$ & $1360-1480$ \\
\hline PM3 & 65 & $3.62 \pm 0.03$ & $10.14 \pm 0.18$ & $2.94 \pm 0.08$ & 5.9 & $10 \pm 5$ & $4.67 \pm 0.29$ & 49 & $100-150$ & $1.35 \pm 0.04$ & $287 \pm 22$ & $1700-1745$ \\
\hline PM2 & 117 & $2.96 \pm 0.02$ & $13.35 \pm 0.27$ & $3.50 \pm 0.06$ & 10.5 & $15 \pm 5$ & $4.22 \pm 0.29$ & 49 & $100-150$ & $4.74 \pm 0.22$ & $1121 \pm 91$ & $795-980$ \\
\hline PM1 & 165 & $2.93 \pm 0.03$ & $13.65 \pm 0.17$ & $3.69 \pm 0.07$ & 12.9 & $15 \pm 5$ & $4.25 \pm 0.29$ & 48 & $100-150$ & $5.21 \pm 0.21$ & $1226 \pm 95$ & $685-875$ \\
\hline VER3 & 15 & $3.29 \pm 0.03$ & $11.57 \pm 0.10$ & $5.10 \pm 0.08$ & 20.8 & $20 \pm 5$ & $5.43 \pm 0.40$ & 59 & $100-150$ & $0.20 \pm 0.01$ & $34 \pm 6$ & 1970-1980 \\
\hline VER2 & 45 & $3.94 \pm 0.03$ & $8.40 \pm 0.22$ & $3.41 \pm 0.02$ & 8.0 & $10 \pm 5$ & $5.00 \pm 0.35$ & 49 & $100-150$ & $0.68 \pm 0.07$ & $137 \pm 17$ & $1855-1890$ \\
\hline VER1 & 75 & $3.89 \pm 0.03$ & $11.22 \pm 0.20$ & $4.56 \pm 0.03$ & 12.6 & $15 \pm 5$ & $4.96 \pm 0.33$ & 49 & $150-200$ & $0.65 \pm 0.05$ & $130 \pm 13$ & $1865-1890$ \\
\hline
\end{tabular}


hydrological situation. The contribution from cosmic dose rate followed Prescott and Hutton (1994). All age calculations were performed using ADELE software, and dosimetric data is summarized in Table 2.

\section{Land use history}

Land use history was studied via cadastral documents (Privolt, 2009), photo interpretation of aerial photographs (data collected and analyzed by Jacqueminet et al., 2013), and analysis of old photographs and artworks (Privolt, 2010).

The document produced by the first centralized cadastration (called Napolenic in France) allows us to reconstruct land use since the beginning of the nineteenth century. It consists of two sets of data: the first map and parcel registration of the early nineteenth century (A.D. 1820 in the present case) and a revised registration about one century later (A.D. 1914 in the Yzeron basin). These documents provide precise information (at the scale of each parcel) concerning land use, which is classified by its nature (e.g., ploughlands, vineyards, orchards, meadows, woodlands, etc.). The revised record of A.D. 1914 registered the changes that had occurred during the nineteenth century, and it can thus be usefully compared with the previous document. In order to follow the more recent landscape evolution, aerial photographs of the studied reaches were collected. These were interpreted using the same land use classification as in the cadastral maps. All land use data were integrated into GIS. In each catchment, each parcel shown by the cadastral map was digitized and associated with a table describing the land use at four dates (A.D. 1820, A.D. 1914, A.D. 1970, A.D. 2008). The use of GIS allows the estimation of surface evolution through time and some semiquantitative or qualitative analysis (level of spatial fragmentation of a type of land use, connectivity) as it is commonly practiced in landscape ecology analyses.

Nevertheless, contrary to aerial photographs, cadastral documents give insufficient precision to reconstitute all characteristics of countryside landscapes. Indeed, at the time of its conception, the land registry aimed to evaluate owners' fiscal contributions and not to describe landscapes. Hence, we paid critical attention to two points. First we had to verify that fiscal classes corresponded to effective land use at the time of registration. The second point concerned parcels' boundaries, which can be occupied by hedgerows, woodbanks, or lynchets and which never appear on cadastral maps. As shown by Rackham (1986), lynchets are the result of soil creep in ploughlands when earth moves downhill and accumulates against the lower field boundary. These features are very common in some European regions. This is a critical point insofar as, after several centuries, these lynchets constitute efficient barriers to downhill sedimentary transfer and can have a strong influence on sedimentary supply to valley bottoms. Field observations showed that no similar features currently exist in the studied catchments. However, taking into account that extensive agricultural alterations occurred in the second half of the twentieth century, we must verify that such lynchets or hedgerows did not exist in the past. For these two reasons, we collected a set of old photographs and artwork representing the local countryside (Privolt, 2010). The set of ancient documents was also studied in order to acquire information about land use before the beginning of the nineteenth century (Privolt, 2010). However, because of the small amount of data few data on these ancient documents, only a qualitative interpretation was possible.

\section{Results}

\subsection{Stratigraphic description}

\subsubsection{Chaudanne River section}

In the Chaudanne River, we investigated a 3.5-m-long sediment section (Fig. 2). The age of the sediment deposits is determined by an in situ tree trunk found $1 \mathrm{~m}$ away from the outcrop. Another trunk was found in a similar position about $20 \mathrm{~m}$ upstream. These and ten other tree trunks found along the presently incised channel are Populus, Salix, and Alnus glutinosa/incana, indicating a humid, riverine environment. Radiocarbon dating of the two trees located close to the investigated section gave ages of A.D. 1460-1630 (ULA-1141; Table 1) and A.D. 1520-1655 (ULA-1140; Table 1). This indicates that deposition of the sediment sequence took place after about A.D. 1500. In the field, the stratigraphy has been divided into nine sedimentary units (SU) according to the color, structure, and lithology of deposits.

Units 1 and $2(350-175 \mathrm{~cm})$ consist of laminated silty-sands wherein ochre coarse layers are stratified with bluish fine layers. The dominant sandy fraction ranges between 63 and 88\%, and the fine fraction (silts and clays) from 11 to $29 \%$. These units are intercut by a very coarse layer at a depth of $265-245 \mathrm{~cm}$, wherein the proportion of pebbles is around $20 \%$. Conversely, a layer enriched in fine particles at a depth of $189 \mathrm{~cm}$ show a silty-clayed fraction of $62 \%$. The MS values are relatively homogeneous as they fluctuate between 0 and 17 CGS (mean value: 5). Similarly, LOI values vary slightly, between 1 and 3\%, except for the thin layer at $189 \mathrm{~cm}$ which comprises $8 \%$ LOI.

The yellow-orange sedimentary facies of SU $3(175-130 \mathrm{~cm})$ incorporates very coarse particles; it contains on average more than $70 \%$ sands and only $6 \%$ fines. The remaining sediments are composed of granules and gravels. This sedimentary facies change is also reflected by a decline of MS and LOI average values, which are - 0.2 CGS and $0.5 \%$, respectively.

The bluish SU $4(130-87 \mathrm{~cm})$ suggests a return toward quieter depositional conditions as indicated by the decrease of the coarse and sandy fractions (respectively, mean values: 1 and 65\%) in favor of silts (32\%) and clays (2.5\%). This change coincides with increasing values of MS and LOI that reach, respectively, 4 CGS and $4 \%$.

The extremely coarse SU $5(87-75 \mathrm{~cm})$ is composed of grayish sediments containing $42 \%$ of particles with grain size exceeding $2 \mathrm{~mm}, 52 \%$ sands, and $<7 \%$ fine particles $(<63 \mu \mathrm{m})$. This sharp change in the sedimentary facies is again reflected in the decreasing values of MS and LOI, which respectively fall to averages around 1.3 CGS and $1 \%$.

The darkish SU 6, 7, 8, and $9(75-0 \mathrm{~cm})$ show a homogeneous facies, with a texture dominated by sands (mean value: $51 \%$ ) and fines (mean value: $43 \%$ ). Moderate conditions of transport and deposition are implied by the increasing LOI content, which reaches $9.5 \%$. The maximum MS values in this section are recorded within these units (mean value: 17.4 CGS). This peak could be explained by the development of pedogenic processes in the upper part of the section. Indeed, we suppose these MS values are closely linked to the vertical migration of Fe-Mn oxy-hydroxydes from the upper pedologic layer toward the accumulation horizon.

\subsubsection{Bouillon River section}

In the Bouillon River we investigated a 2.5-m-long sediment section (Fig. 2). According to OSL dating, basal sediments were deposited during the seventeenth century. These ages are coherent with those from the basal part of the Chaudanne River section. Conversely, we consider that the radiocarbon age of A.D. 1045-1225 (Lyon-6271; Table 1) determined for a charcoal within this section is likely to be reworked material.

The sedimentary unit $1(250-200 \mathrm{~cm})$ comprises darkish gray sands (79\%) incorporating coarse particles (11\%) and fines (10\%) to a lesser extent. The MS and LOI values are low, respectively, $<1$ CGS and $1.2 \%$.

The sedimentary environment changes abruptly: unit 2 (200$175 \mathrm{~cm}$ ) is mostly composed of dark grayish coarse particles (57\%) to the detriment of the sand fraction (33\%), but the proportion of the fine fraction remains stable (10\%). The increase in transport energy suggested by the particle size analysis is not apparent in the MS and LOI values, which remain stable (respectively, 1.5 CGS and 1.9\%).

The sedimentary unit $3(175-65 \mathrm{~cm})$ consists of laminated siltysands, with interstratified ochre sandy layers and bluish fine layers. While coarse deposits may show up to $93 \%$ sands $(82 \mathrm{~cm}$ ), the same level yields only $4 \%$ fine particles. In contrast, when fine deposits 


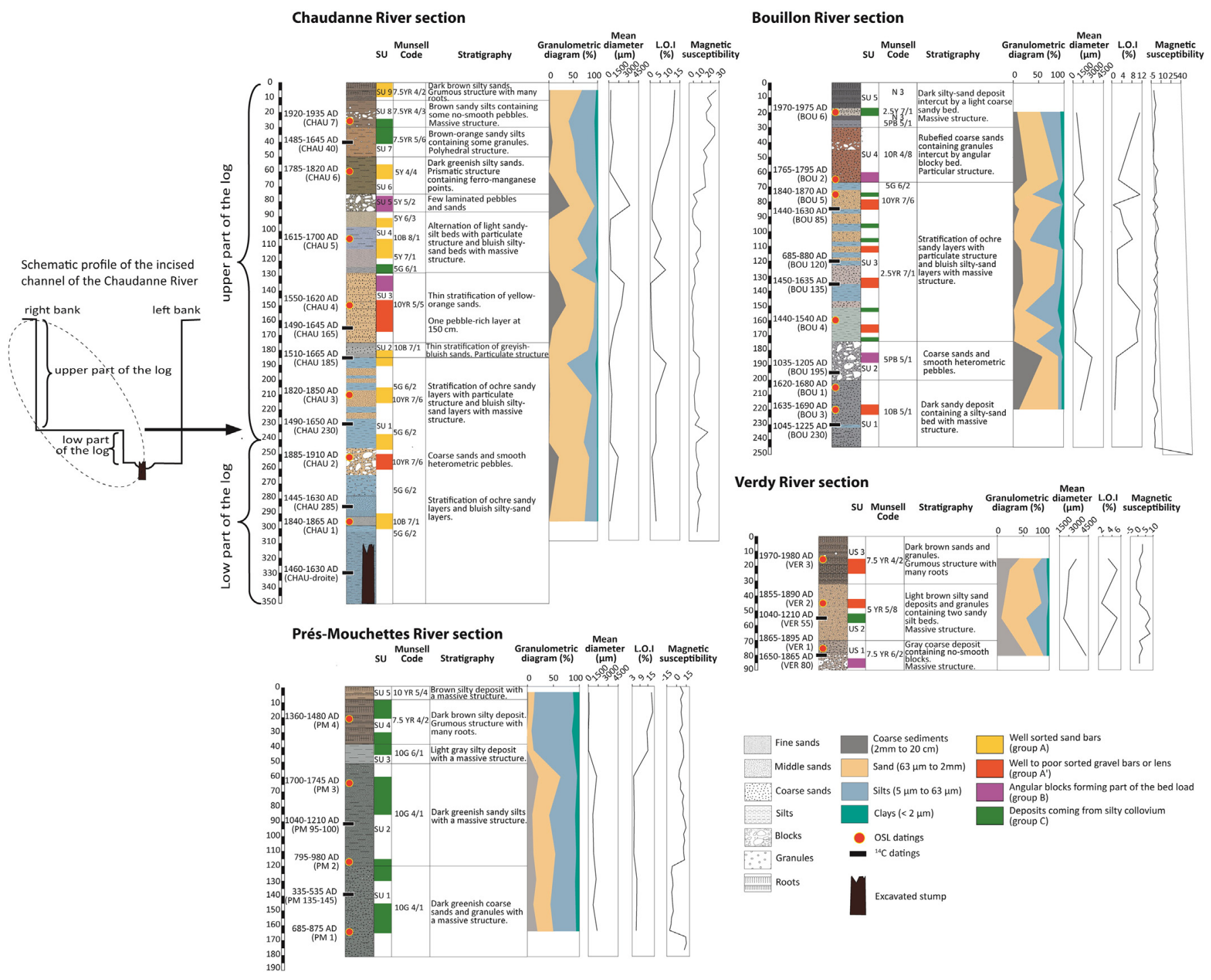

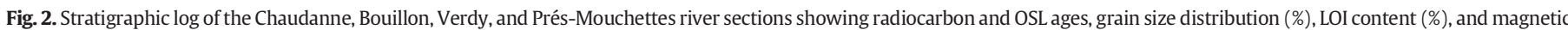

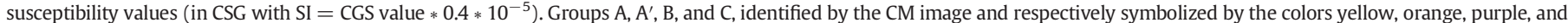
green, are detailed in Fig. 7. SU = Sedimentary Unit.

dominate in the section, silts and clays may reach up to $70 \%(153 \mathrm{~cm})$, and sands fall to $22 \%$. The LOI values reach up to $11 \%(153 \mathrm{~cm})$ in fine sediments and decrease to $0.5 \%(82 \mathrm{~cm})$ in sandy layers. The MS values remain similar to unit 2 (mean value: 1.7 CGS).

The sedimentary unit $4(65-30 \mathrm{~cm})$ is characterized by rubefied coarse sandy layers (62\%) containing granules and intercut by a bed of angular blocky particles (27\%). The MS values continue to fall, becoming negative (mean value: -1 ), and LOI content remains relatively low (2.6\%).

A change in sedimentary facies occurs with the darkish unit 5 (30$0 \mathrm{~cm}$ ), which reaches $47 \%$ fine particles and $46 \%$ sands. This weakening of transport and depositional energy is expressed through the increasing LOI content $(11 \%)$ but does not affect MS, which remains stable (mean value: 0 CGS).

\subsubsection{Verdy River section}

Along the Verdy River, we investigated a 0.9-m-long sediment section (Fig. 2). In contrast to the previously described sections, this one does not display a trunk at its base. This is not surprising because of the relatively recent age of this sediment section (eighteenth century).

The sedimentary unit $1(90-70 \mathrm{~cm})$ consists of a grayish coarse deposit containing angular blocks. Granulometric fractions are divided as follows: $57 \%$ coarse sediments, $33 \%$ sands, and $10 \%$ fines. This highenergy environment produced weak values for MS and LOI, 1.5 CGS and $1 \%$, respectively.

The sedimentary unit $2(70-32 \mathrm{~cm})$ is a light brown silty-sand deposit containing two sandy-silt beds. The decreasing transport and depositional energy is characterized by a decrease of the coarse fraction (mean value: 16\%) and an increase of the fine fraction (mean value: $29 \%$ ). This evolution is correlated with MS and LOI values that are elevated with respect to those of SU 1 (mean values: 4 CGS and $1.7 \%$, respectively). It is clear that energy remains relatively high, however, owing to the significant sandy fraction (mean value: $56 \%$ ) in this unit.

The sedimentary unit $3(32-0 \mathrm{~cm})$ is a dark brown sandy deposit containing granules, which cause an increase in the coarse fraction (mean value: 35\%) and a concomitant decrease in sands and fine sediments (mean values: 43 and $22.5 \%$, respectively). This upper organic deposit is marked by the highest LOI mean value (4\%) and the lowest MS mean value (1.4 CGS).

\subsubsection{Prés-Mouchettes River section}

At Prés-Mouchettes River we investigated a 1.8-m-long sediment section (Fig. 2). This section is nearly a millennium older than the Chaudanne and Bouillon sections, if compared to the deepest samples 


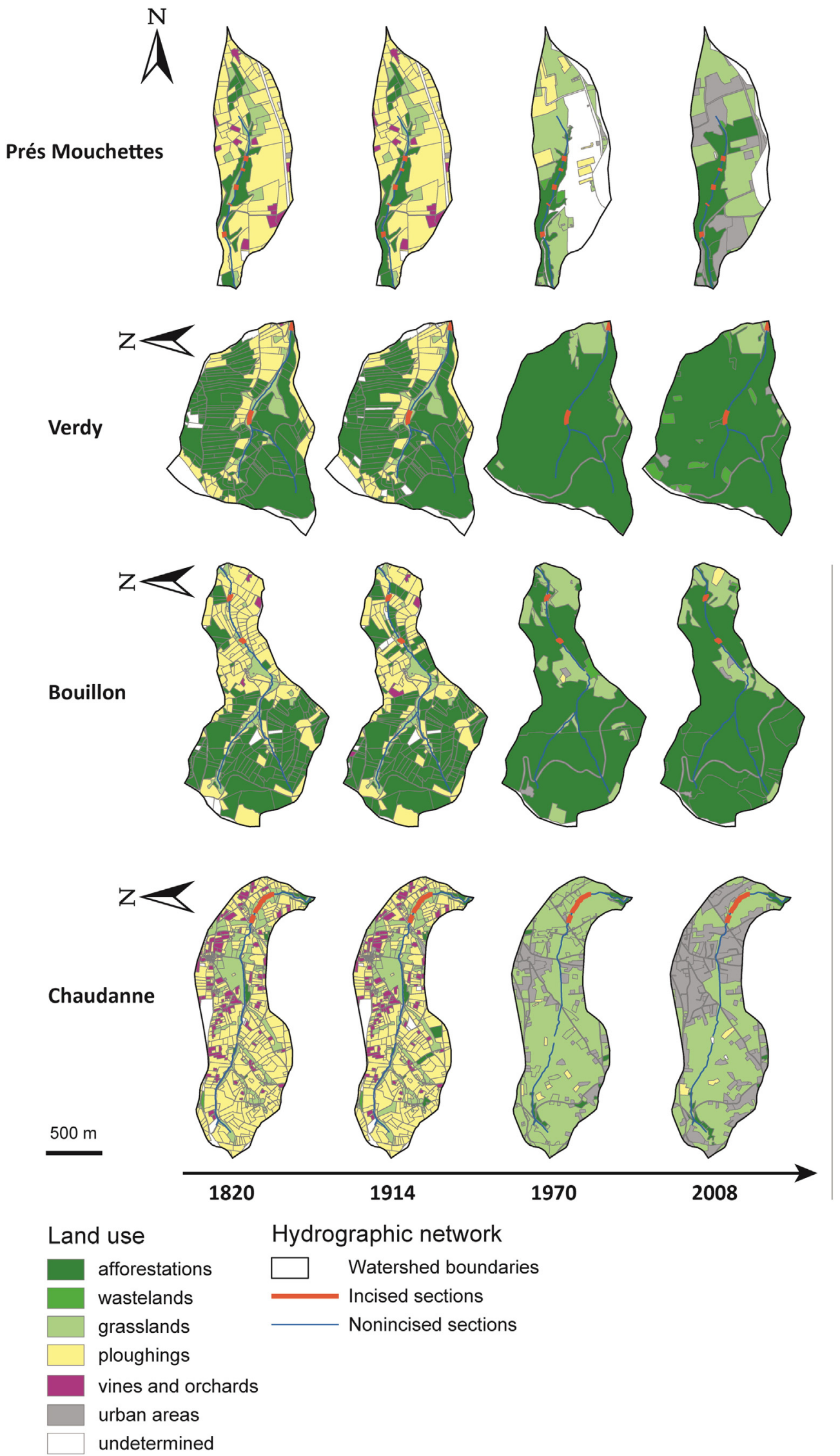

Fig. 3. Diachronic maps of land use since A.D. 1820 of the four subcatchments studied. 

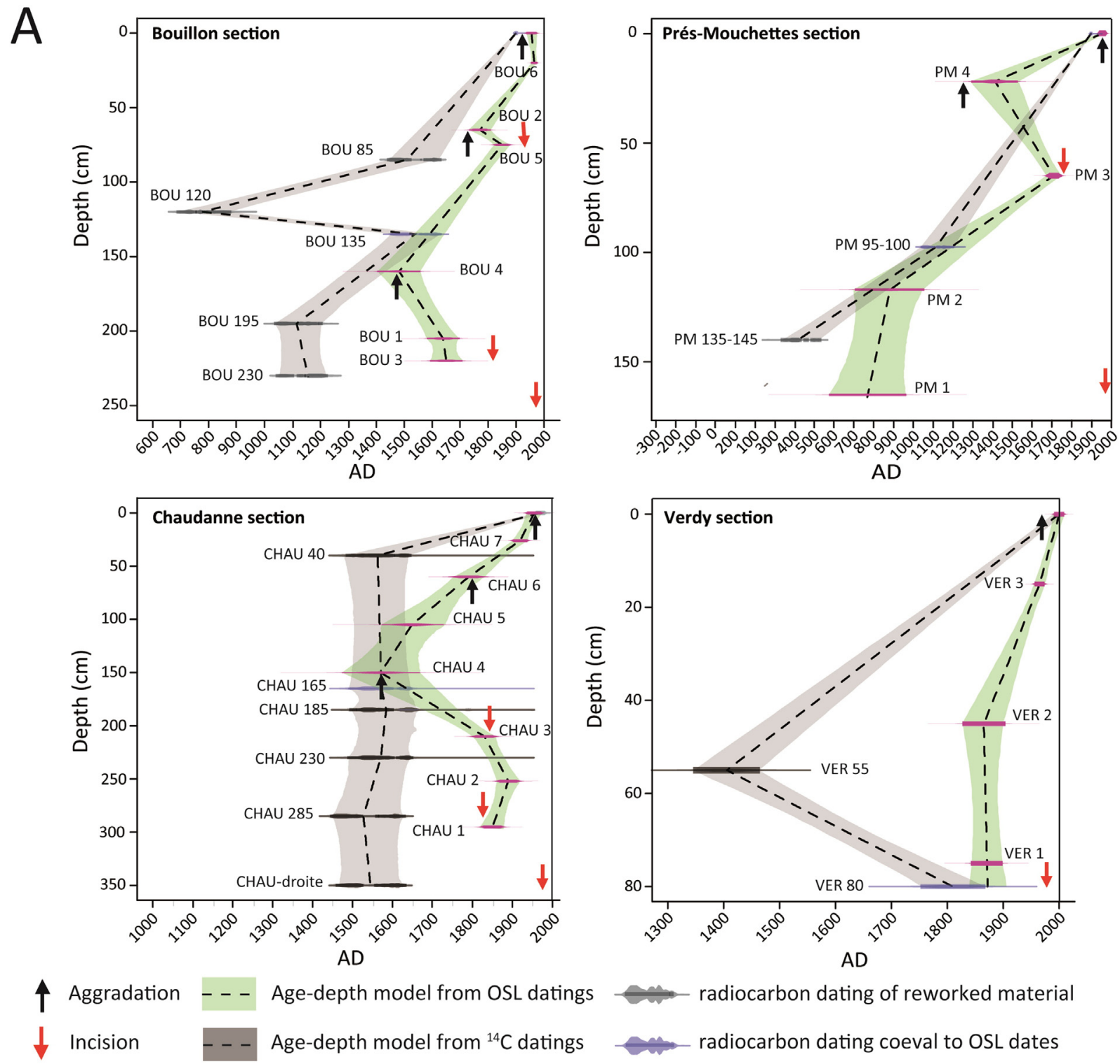

radiocarbon dating of reworked material radiocarbon dating coeval to OSL dates OSL dating

B

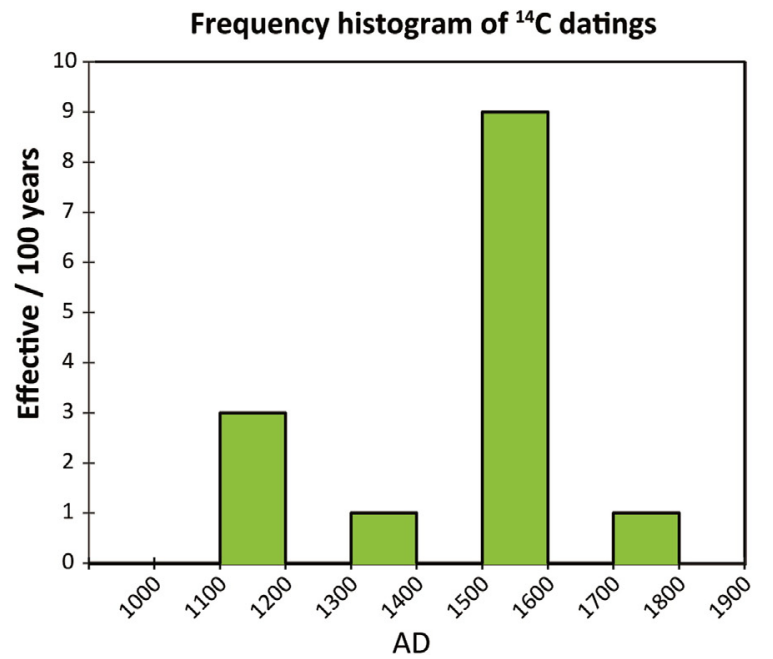


dated by OSL in these locations (CHAU1 and BOU3, respectively). Moreover, the profile of the section is remarkably homogenous, as observed by the extremely weak vertical variations in sedimentological proxies.

The sedimentary units 1 and $2(180-50 \mathrm{~cm})$ gave OSL ages ranging from A.D. 685-875 (PM1; Table 2) to A.D. 1700-1745 (PM3; Table 2). These dark greenish sandy silts contain on average $16 \%$ gravels, $35 \%$ sands, and $49 \%$ fines, without any major variation. The LOI values also show only weak variations, ranging between 4.1 and 6.6\%. Only MS values vary significantly between units 1 and 2 . While the values of the first evolve from positive (mean value: 14 CGS) to negative (mean value: -7 CGS), MS is only positive in the SU 2 (mean value: 9.5 CGS).

The depositional environment changes in SU $3(50-0 \mathrm{~cm})$ as brown fine particles (mean values: $89 \%$ ) increase and sandy and coarse fractions decrease (mean values: 0.7 and $10.6 \%$, respectively). This lowenergy environment is characterized by an increase in LOI content of $16.5 \%$ on average, whereas MS values (mean value: 8 CSG) remain high.

\subsection{Landscape evolution}

Land use mapping reveals that landscape evolution can be divided into two distinct periods between 1820 and 2008 (Fig. 3). During the whole nineteenth century and until the beginning of the twentieth, cadastral data show that a major part of these catchments was covered by cultivated surfaces (principally registered as ploughlands). We can add that these maps hide a significant growth in cereal crops, orchards, and vineyards in the mid-nineteenth century, which is indicated by agricultural statistics and historical studies. Indeed, the agricultural peak occurred around 1860, which also corresponded to a peak in the farming population (De Farcy, 1950). For example, at this time vineyards accounted for $1 / 5,1 / 6$, and $1 / 8$ of the municipal areas of Brindas, Craponne, and Francheville, respectively, in the Plateau Lyonnais (De Farcy, 1950). Grasslands were only present in the valley bottoms.

The second trend shared by the four studied catchments is a significant decrease in ploughlands since the second half of the twentieth century (Fig. 3). This decrease, which began slowly at the end of the nineteenth century, gained momentum in the 1960s with an economic reconversion of local agriculture called révolution fourragère (Chazal et al., 1955; Houssel, 2006). In order to enhance fodder production, many croplands were gradually converted to grassland (mainly permanent grassland). At the same time, woodland or urban areas replaced some former ploughlands as an effect of agricultural desertion of the steepest hillslopes and Lyon's urban sprawl. Spontaneous or humaninduced reforestation occurred mainly in the Monts du Lyonnais, whereas urbanization mostly affected the Plateau Lyonnais (Fig. 3). In the Yzeron basin, ploughlands represented $34 \%$ of basin surfaces in 1904 compared to only $12 \%$ in 2000 . In addition, the general decline of agriculture was very pronounced: in the same period, the proportion of cultivated areas in the basin decreased from 91.7\% to 59.9\% (Cottet, 2005). In the studied reaches, we can distinguish two cases. In the Chaudanne and Prés-Mouchettes catchments, ploughlands covered $52 \%$ to $63 \%$, respectively, of the total basin surface until the beginning of the twentieth century In the Verdy and Bouillon catchments, ploughlands represented between $32 \%$ and $42 \%$, respectively, of the total surface during the same time. In all basins, ploughland proportions quickly decreased after the 1960s and currently range between $<1 \%$ (Chaudanne) and 0.28\% (Bouillon).

Historical mapping also reveals changes in landscape structure that we may consider as important as changes in land use. Since the second half of the twentieth century, ploughlands have become extremely fragmented, existing only as small and isolated patches. By contrast, during the previous century, these ploughlands formed a continuum along hillslopes, often constituting large patches 500 to $700 \mathrm{~m}$ long and well connected to valley bottoms. This spatial setting is favorable to sediment transfer from slopes to riverbeds. The analysis of old photographs and artworks representing the local countryside (Privolt, 2010) reveals that the open landscapes constituted the major fraction of these catchments. In these pictures, only a few hedgerows or woodbanks appear at the boundaries of plowed parcels. We could not distinguish significant evidence for buffers or obstacles along slopes that would be remnants of previous wooded boundaries or colluvial lynchets. Moreover, some artwork dating to the seventeenth and eighteenth centuries and representing the neighborhood of Lyon show the same type of land use. Some hedgerows are present, but most of them are directed toward the slope and they never appear to constitute a closed network. Although the use of paintings or engravings for reconstituting environmental features of the past requires a critical view, the recurrence of previously cited characteristics of local landscapes through three centuries suggests that they might have begun as early as the seventeenth century. This finding is consistent with historical works reporting intense plowing from the end of the Middle Age to the nineteenth century (De Farcy, 1950; Lorcin and Houssel, 2008). This historical information tends to support the hypothesis that past landscapes were quite open and characterized by a good connectivity between slopes and riverbeds. Such features can explain the thick sedimentary fill currently present in valley bottoms.

\section{Discussion}

\subsection{Identification of aggradation-incision phases}

The OSL and radiocarbon age-depth models of the four stratigraphic sections exhibit an obvious chronological offset, as radiocarbon dates tend to be earlier than OSL ages (Fig. 4A). This first observation confirms the limits discussed in the introduction concerning radiocarbon dating, which might overestimate the age of deposits (Lang and Hönscheidt, 1999) caused by the presence of reworked materials (Lang et al., 1999). Below we will add information obtained from the radiocarbon ages frequency (Fig. 4B).

The second main observation concerns the S-shape of the OSL model age curves (Fig. 4A), that is, the presence of several chronological inversions in the Bouillon, Chaudanne, and Prés-Mouchettes sections. Indeed, some deposits located at the Bouillon (between 230 and $190 \mathrm{~cm}$; BOU3, A.D. 1620-1680, $220 \mathrm{~cm}$; and BOU1, A.D. 1630-1690, $205 \mathrm{~cm}$ ) and the Chaudanne (between 300 and $200 \mathrm{~cm}$; CHAU1, A.D. 18451875, $295 \mathrm{~cm}$; CHAU2, A.D. 1885-1915, $252 \mathrm{~cm}$ and CHAU3, A.D. $1825-1855,210 \mathrm{~cm}$ ) sections were emplaced later than others located above. This OSL dating inversion also occurs in the top part of the Prés-Mouchettes stratigraphy at $65-\mathrm{cm}$ section depth (PM3, A.D. 1700-1740), where upper sediments have been deposited between A.D. 1360 and 1480 at around 22-cm section depth (PM4). Another inversion near the top of a section occurs on the Bouillon at $75-\mathrm{cm}$ section depth (BOU5, A.D. 1845-1875) with upper sediments dated around A.D. 1760-1800 (BOU2) at 65-cm depth.

At first sight, these inversions could be the result of a lower alluvial terrace forming in the channel at the bottom of the banks. This terrace would correspond to a stage of fluvial incision (consequently leading to the presence of younger deposits at the bottom of the sections investigated). Logically, such a pattern would require that this lower terrace yielded the most recent age in the entire stratigraphy. However, this does not seem to be the best explanation, for several reasons. First of all, in the Chaudanne and Bouillon Rivers, the OSL ages for the upper part of the deposits (e.g., Chau7, BOU 5, 2, and 6) give posterior dates

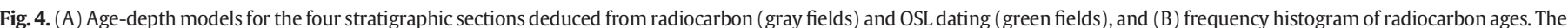

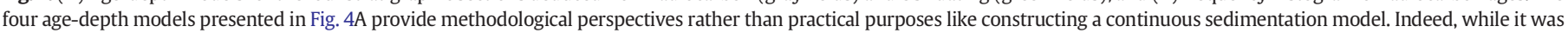

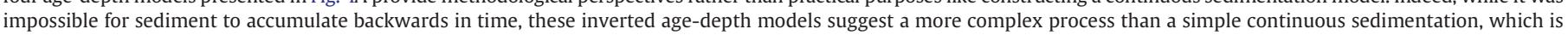
conventionally observed in this kind of graph. (For interpretation of the references to color in this figure legend, the reader is referred to the web version of this article.) 
to those from the bottom. Another key to interpretation is given by the observation of current processes in channels of the studied basin. Indeed, the present-day conditions of fluvial incision does not allow the development of low terraces but rather favors the formation of frequent underbank scours, as we show in Fig. S1. This kind of evolution can easily be explained by the narrowness of the valley bottoms where the shear stress is high and the lateral erosive dynamics are efficient.

Rather, the radiocarbon and OSL dates suggest alternating, rapid incision and deposition processes (Figs. 5 and 6). Except for the particular case of samples CHAU1-2 (see below), the inversions related to the samples CHAU3, BOU3, BOU1, BOU5, and PM3 can be interpreted as short incision phases that have been quickly followed by sediment deposition into underbank excavations (Figs. 5 and 6). The latter, which are common in nonbedrock channels, are explained by the fact that riparian tree roots are highly efficient at controlling lateral erosion and mass failure (Zaimes et al., 2004; Wynn and Mostaghimi, 2006). Consequently, when incisions are deeper than roots (current incision depths are around 3.50, 2.50, 1.80, and $0.90 \mathrm{~m}$ for the Chaudanne, Bouillon, Prés-Mouchettes, and Verdy rivers, respectively), underbank scour is frequent. This scouring process is particularly active and widespread during the incision stage (Figs. 5 and 6). It can also be observed currently in many entrenching channels of the Yzeron basin (Fig. S1), and this process has already been suggested by Preusser et al. (2011) to explain sample CHAU3. Therefore these chronological inversions may result from previous incision phases where subsequent and dated aggradational phases constitute the terminus ante quem of the incision phases. The OSL dating can therefore be used to determine the chronology of the phases of sediment deposition and incision in headwater subbasins (Figs. 5 and 6). Indeed, they are extremely sensitive to external factors (land use, climate, etc.) and the lateral development of underbank scourings can attain a relatively high dimension compared to the channel width, especially as the width to depth ratio is comparatively low in this kind of channel (Schmitt et al., 2001).

Concerning the particular OSL dates of CHAU1-2, Fig. 2 indicates that the shape of the bank presents a bench at a depth of $240 \mathrm{~cm}$ with a width of $188 \mathrm{~cm}$. While OSL samples CHAU1-2 have been taken from a lower bank in the channel, samples CHAU3-7 are from the main exposure. After a first incision on the Chaudanne, a subsequent phase of aggradation followed by a second incision, which reached a lower level than the first incision, led to the deposition of samples CHAU1-2 (Fig. 5). The inversions of these samples are not linked to underbank excavation like other inversions mentioned above but to the successive incision/aggradation phases and the particular bank morphology (bench) of the Chaudanne section during sample collection (Preusser et al., 2011).

Incision phases operate at different times in the four stream channels studied. The Bouillon River was incised during the seventeenth century (Fig. 6) whereas it occurred in the eighteenth century for the Prés-Mouchettes River, and in the nineteenth century for the Chaudanne River (Fig. 5). This latter phase in the nineteenth century could have taken place also on the Bouillon River (BOU5, A.D. 18451875; Fig. 6). The absence of any incisions dated to the seventeenth century in the Chaudanne River section (Fig. 5) could be explained by upstream sedimentary removal (from the Monts du Lyonnais and partly the Plateau Lyonnais) at this time causing downstream infilling (Plateau Lyonnais). This correspondence between upstream headwater channel incision and downstream river fine deposits is currently observed in the Yzeron's catchment, the disturbing effects of which (biocenoses, flooding) are precisely the reason for the geomorphic studies conducted in this basin over the past 10 years (Grosprêtre, 2011). Only the OSL ages measured on the Verdy River sediments do not display chronological inversions, as sedimentation was continuous (Fig. 4A). This state is consistent with results obtained on the three other watercourses, which do not show any incisions after the end of the nineteenth century (except modern incision); the studied section of the Verdy River is younger than this period.
Incision phases cited above are preceded by an aggradation phase in the valley bottoms that began in the early sixteenth century (Figs. 5 and 6). At this point, OSL and radiocarbon ages seem to agree: they are similar with regard to the stratigraphic sections of the Chaudanne (around $150 \mathrm{~cm}$ ) and Bouillon rivers (between 160 and $135 \mathrm{~cm}$ ) (the gray and green fields of the age-depth models overlap as early as A.D. 1500; Fig. 4A). In other words, OSL dating, in concert with radiocarbon ages and the absence of palaeosoils within the sequences, indicates rapid aggradation at valley bottoms owing to a substantial flux of sediment from hillslopes. Deposition began shortly after A.D. 1500 at the valley bottoms of the Chaudanne and Bouillon rivers (Figs. 5 and 6), probably before those of the Prés-Mouchettes River, and continued until about A.D. 1800 for the Chaudanne River, A.D. 1700 for the Prés-Mouchettes River, and A.D. 1600 for the Bouillon River. The dating of this thick sedimentary filling appears consistent with the characteristics of land use we described above. Indeed, the weak resistance of cultivated surfaces to erosion is explained by the significant runoff over these areas that do not benefit from a protective vegetation cover. This process is related to the development of diluted or concentrated flows on the stripped surfaces causing colluviation on the footslopes up to several centimeters per year (Bertran and Texier, 1997).

High sedimentation rates during this period were also found in southern, southwestern, and central France (Allée, 2003; Bertran, 2004; Miras et al., 2004) as in other regions (Lespez et al., 2015). In the Belgium Ardennes massif, Notebaert et al. (2013) showed that the floodplains' contemporary storage was accumulated during the last 600 years because of increased sedimentation rates related to agricultural activities. In the Lyon region, the first evidence for valley bottom aggradation is observed from the sixteenth century, though the development of agriculture has occurred since at least the early fourteenth century (Lorcin, 1974). Therefore human activity anterior to the LIA could have already destabilized the hillslopes, and thereby subsequently amplified the LIA climatic signal. In this regard, Macklin and Lewin (2003) noted that climatic signals can be amplified or attenuated by human land use, particularly in small-sized river basins.

While the history of land use of the four studied subcatchments since A.D. 1820 (Fig. 3) supplies detailed information concerning catchment-scale human activities, the frequency of radiocarbon ages is also highly instructive for prior periods. Fig. 4B shows two relatively important modes in the radiocarbon age distribution that are centered on the twelfth and sixteenth centuries. The radiocarbon age frequency of the latter period is much higher than that of the former period. As specified above, these charcoals from the sixteenth century are coeval with deposits dated by OSL, as OSL and ${ }^{14} \mathrm{C}$ age-depth models overlap. Such nonuniform distribution could result from a release of charcoal as a result of land-clearing (Horn and Sanford, 1998; Clement and Horn, 2001) intended to increase cropland area (Berger et al., 2002; Vannière and Laggoun-Defarge, 2002; Franc, 2005; Bertoncello, 2008).

The smaller mode centered on the twelfth century (Fig. 4B) could be related to the rapid population growth and land-clearings in the Monts du Lyonnais and the Plateau Lyonnais (Lorcin and Houssel, 2008; Rubellin, 2009) during the time of the Medieval Agricultural Revolution (Duby, 1954). In contrast to the sixteenth century mode, this lower radiocarbon age frequency represents charcoals that are not coeval with the timing of sediment deposition because the OSL and ${ }^{14} \mathrm{C}$ age-depth models do not overlap during the twelfth century for the Bouillon section (Fig. 4A). This period corresponds to the large deforestation phases operating at the European scale (Monna et al., 2005). The occurrence of this phase of land-clearings during the twelfth century was likely to have caused an early aggradation stage of the bottom valley of the Bouillon River, as was the case during the sixteenth century.

When the number of radiocarbon dates is large enough, inspection of the dates' frequency histogram is particularly instructive to discriminate potential aging effects. Indeed, the aging of radiocarbon dates can also be caused by the burning of tree rings located in the heart of the stump rather than those toward the exterior. This process, occurring 
(i) 16th - end 18th century

Aggradation

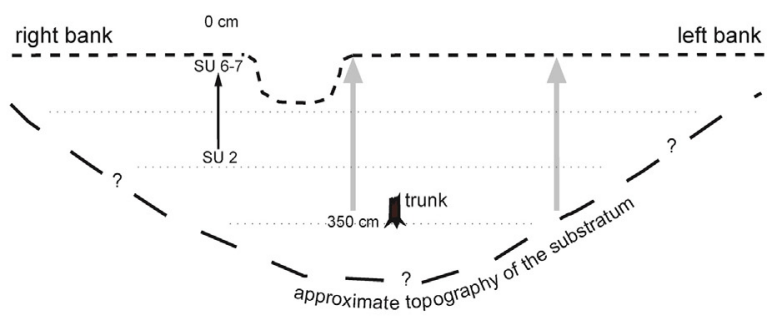

(iii)

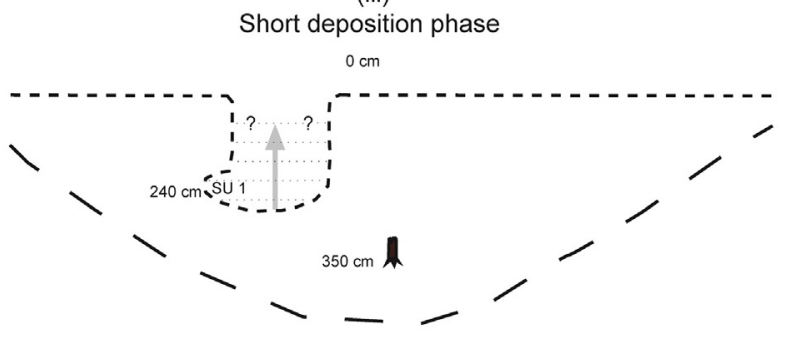

(v) $1840-1975$

Deposition in the incised section and on the valley bottom

(+ hillslope deposits during the beginning of the 20th century)

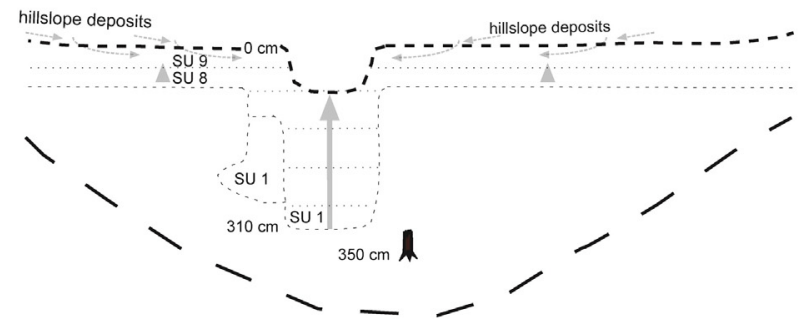

(ii) $1820-1840$

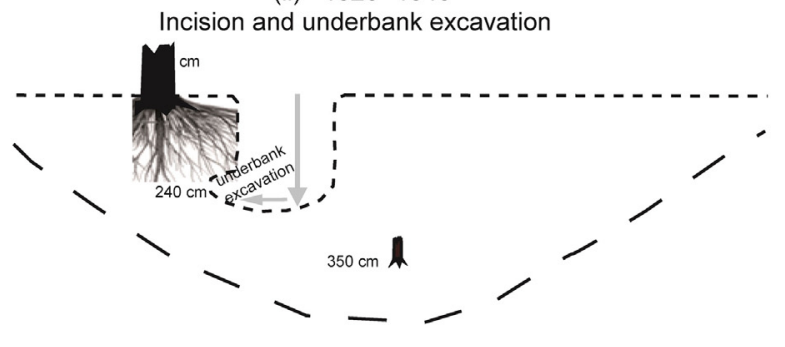

(iv) $1830-1840$

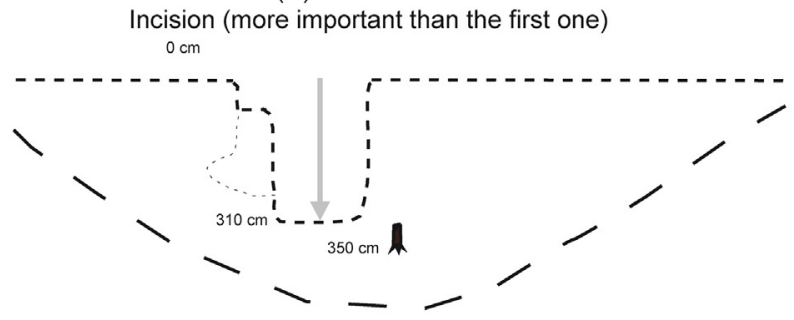

(vi) After 1975

Incision due to decrease of sediment yield basin and in increase of energy ( $\mathrm{UI}$ and $\mathrm{CSO}$ )

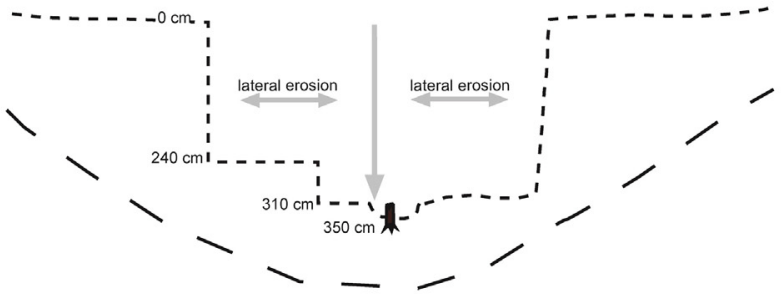

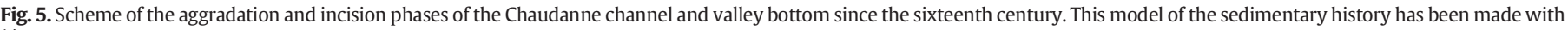
${ }^{14} \mathrm{C}$ and OSL datings.

Modified from Preusser et al. (2011).

randomly within the tree stump, is recognizable by the occurrence of older and isolated radiocarbon dates, which do not lead to the formation of a specific mode in the histogram. As an illustration of this effect, we can cite the example of the charcoal BOU 120, which shows a particularly significant age offset. We do not believe this can be attributed to ancient land clearings because of the lack of other charcoals from the eighth/ninth centuries.

Afterwards, the demographic decrease of the fourteenth and fifteenth centuries, from the plague and the Hundred Years War (Lorcin, 1974; Lorcin and Houssel, 2008), could indirectly explain the low frequency of the recorded radiocarbon ages for this period (Fig. 4B). Finally, the major peak in radiocarbon ages detected for the sixteenth century (Fig. 4B) could be associated with the modern demographic rise, the resumption of land clearing and the conquest of new agricultural surfaces. This trend is perceptible not only in the Lyon neighborhood but also in major parts of the kingdom of France, where it was accompanied by a significant decrease of woodlands (Garnot, 1998).

\subsection{Assessment of sediment-transport processes}

A common technique employed in geomorphology to assess sediment-transport processes is to analyze samples via the CM diagram of Passega (1957), which is based on grain size data (Bravard and Peiry, 1999; Bravard et al., 2014; Delile et al., 2015a,b). Fig. 7 shows this kind of data representation for all samples taken from the four stratigraphic sections. The resulting image differs strongly from the original defined by Passega (1957) or that obtained for large rivers such as the Rhône River (Bravard, 1985; Macé et al., 1991). This singular image encompasses the contrast between two main components that reflect the influence of fluvial (red field) and colluvial (green field) processes (Fig. 7). Hillslope processes are more pronounced in the small watersheds studied (Preusser et al., 2011) where Holocene deposits are typically stored in colluvial fans and hillslope foots (Notebaert et al., 2013). Four groups are easily identifiable within these two components.

The green field integrates deposits coming from silty colluvium with granules mainly from diffuse runoff over plowed lands (C group) and a small part of the $B$ and $A^{\prime}$ groups (Fig. 7). The $C$ group is clearly dominated by the samples of the Prés-Mouchettes River section whose valley bottom is narrower and hillslopes are steeper.

The colluviation is characterized notably by a lower velocity of particle transport, which could explain, at less partly, the older age of the Prés-Mouchettes deposits. We can establish a parallel with Berger et al. (2002) who estimated, in their comparative study of alluvial and colluvial records from the watershed of the Citelle River (middle Rhône valley, left side), that hydrological fluctuations in the colluvium is 10 times lower than in alluvium. The occurrence of colluvium in these deposits is not surprising because this process is enhanced by runoff over croplands (Auzet, 1987, 1990; Bertran and Texier, 1997; Bertran et al., 1998), which were significant from the sixteenth to the early 
(i) end 15th - beginning 17th century Aggradation

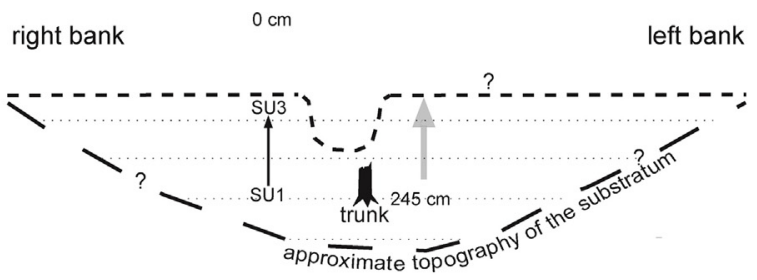

(iii) end 17 th - end 18 th centuries Aggradation

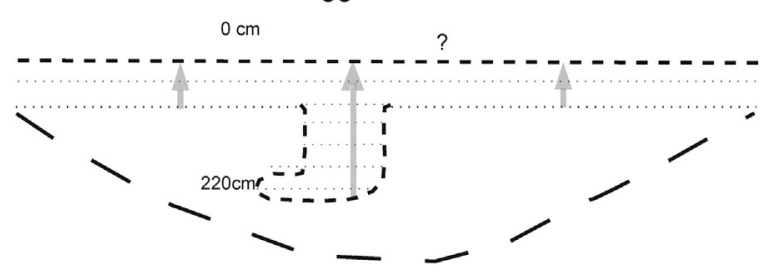

(v) $1840 / 1870-1975$

Deposition in the incised section and on the valley bottom (+ hillslope deposits during the beginning of the 20th century)

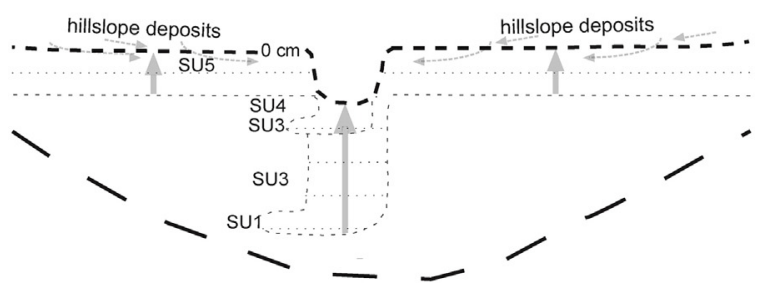

(ii) $\approx 1620-1690$

Incision and underbank excavation

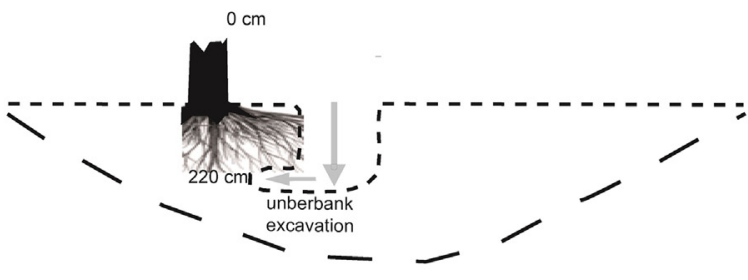

(iv) $1840-1870$

Incision and underbank excavation

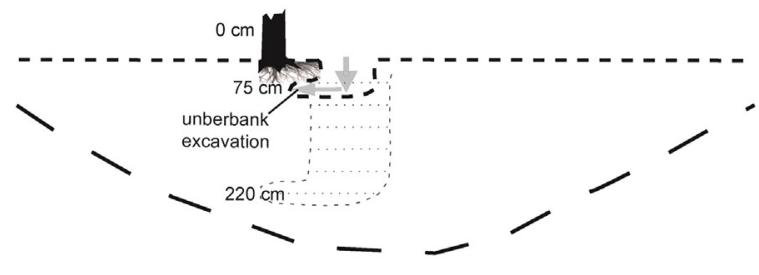

(vi) After 1975

Incision due to decrease of sediment yield basin

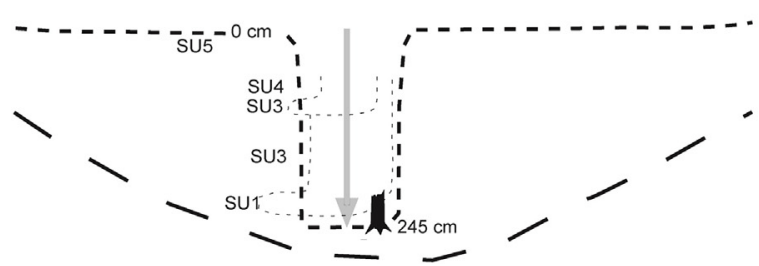

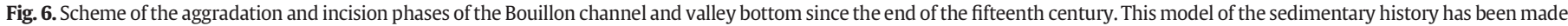
with ${ }^{14} \mathrm{C}$ and OSL datings.

twentieth centuries according to historical studies (Lorcin, 1974; Lorcin and Houssel, 2008; Rubellin, 2009), radiocarbon age frequency (Fig. 4B), and reconstitution of land use evolution (see land use maps of A.D. 1820 in Fig. 3). These particles, mobilized by sheet runoff over plowed fields, could generate a kind of mud flow toward the valley bottoms (Bertran and Texier, 1997). Typically, these colluviums produced by runoff over croplands take the appearance of sheets within the footslopes (Bertran and Texier, 1997).

The red field (fluvial component) contains the $A, A^{\prime}$ groups and a part of the B group (Fig. 7). These deposits correspond to well-sorted bars (graded suspension and rolled granules, A group), and well to poorly sorted gravel bars or lens. The major difference between the two groups is the level of sorting, which is more developed for the A group (Fig. S2). This group is exclusively composed of sediments from the Chaudanne River, whose valley bottom is wider and more flared ( 20 to $60 \mathrm{~m}$ ). The lateral inputs of colluvium are thus relatively restricted (Notebaert et al., 2013). Conversely, the Verdy and Bouillon streams (A' group, Fig. 7) flow through relatively narrow valley bottoms ( $<$ to $20 \mathrm{~m}$ ), where lateral inputs of coarse material are relatively higher (Notebaert et al., 2013). With this in mind, these sand and gravel lenses cause a much faster aggradation of the alluvial floor of the Chaudanne, Bouillon, and Verdy rivers than the previously discussed $C$ group
(Prés-Mouchettes River) because the diffuse flows are able to form stratified sedimentary structures (Bertran and Texier, 1997; Bertran et al., 1998).

\subsection{Proposal of a sedimentary cascade model}

The available age constraints and knowledge of land use allow us to establish a scheme of hydrosedimentary evolution over time in the four catchments. According to the excavated stumps of the Chaudanne river, before the sixteenth century, valley bottoms are more than of $3.5 \mathrm{~m}$ below their current level (Figs. 5 and 6), and are covered by a riparian forest of genus Populus, Salix and Alnus glutinosa/incana (Preusser et al., 2011). At this time, the relatively mild hydroclimatic conditions of the Medieval Climatic Optimum (MCO)-LIA transition period should restrict sediment inputs into the fluvial system. This low sedimentary supply was probably due to relatively small proportion of ploughlands in the watershed (Fig. 4B) so that no or only weak aggradation occurred. This limited land use seems to be strengthened by the absence of colluvial deposits in the basal part of the stratigraphies except for that of the Près-Mouchettes, which is entirely composed of colluvium (Figs. 2 and 7). Consequently, water could have flowed into a single channel (or little anastomosing channels) presenting low lateral dynamics (notably 


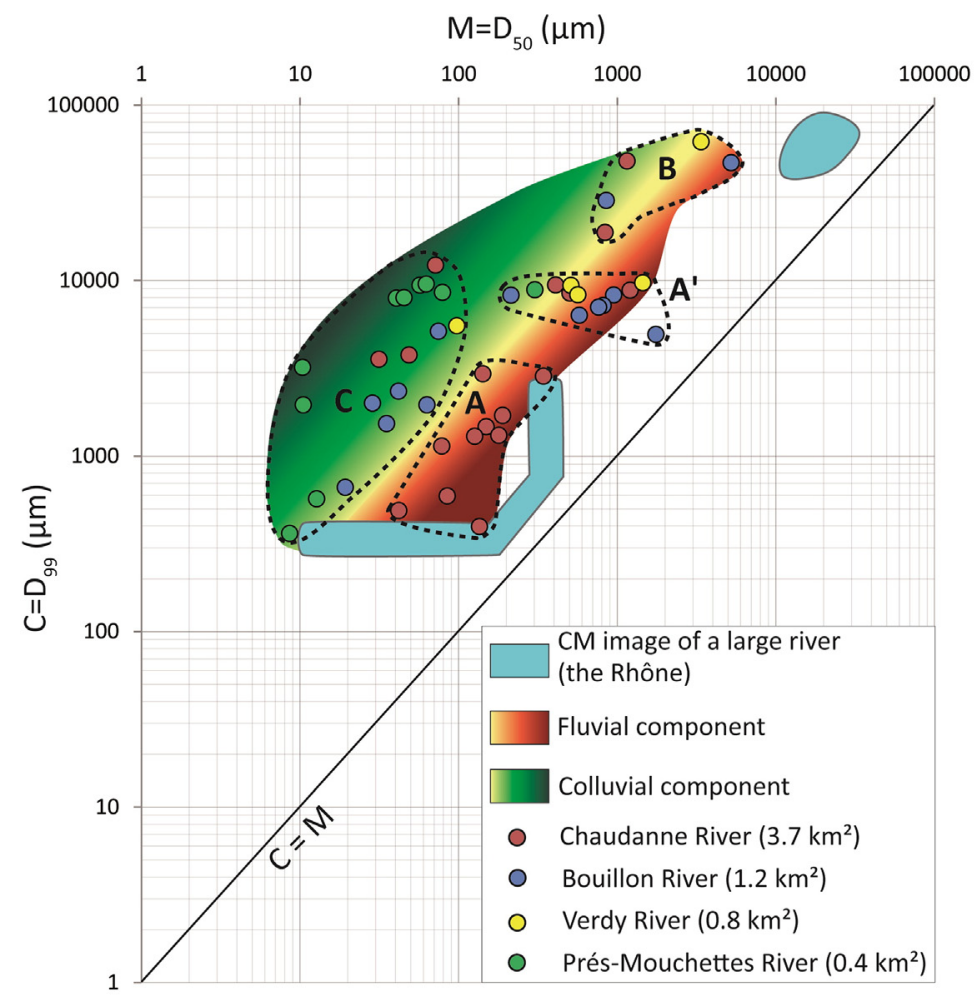

A: Well-sorted sand bars (graded suspension and rolled granules)

$A^{\prime}$ : Well to poor-sorted gravel bars or lens, according to the proportion of sandy matrix in deposits

B: Angular blocks forming part of the bed load or at the limit to the transport capacity of the watercourse

C: Deposits coming from silty colluvium with granules mainly from diffuse runoff on ploughed lands

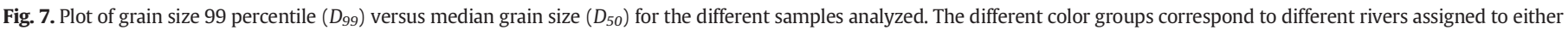

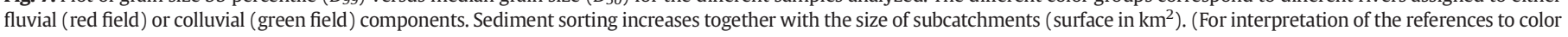
in this figure legend, the reader is referred to the web version of this article.)

from the vegetation) and moderate hydrodynamics. In such conditions, some events could have reworked and transported as bedload the coarsest particles, which probably were provided from remnants of periglacial alluvial sheets or local rocky outcrops, even if minor indirect injections from reworking of colluvial deposits of footslopes should not be underestimated.

The depth of excavated stumps found in the current river bed of the Chaudanne allows us to estimate the thickness of sediments deposited between the sixteenth and nineteenth centuries and thus indicates the level of floodplains before that period (Figs. 5 and 6). This aggradation of the valley floor was logically associated with its lateral enlargement, wherein the channel pattern may have evolved toward an anastomosed style (probably not continuous) with abundant sandy bars. This evolution has concerned flat bottom valleys of the Plateau Lyonnais like those of the Chaudanne River. In the field, we detected evidence for ancient stream beds, probably not continuous over time, throughout the current lateral depressions lining each side of the Chaudanne River floodplain. These were not observed in the Monts du Lyonnais. In general, the aggradation is composed of coarse and relatively well-sorted fluvial deposits (groups A, $\mathrm{A}^{\prime}$ and $\mathrm{B}$ ) in which there are occasional colluvial intrusions (group C) (Figs. 2 and 7). The major source of the coarsest material has shifted toward the reworking of the colluvial footslope deposits, which contain small blocks. Such angular blocks have been detected in a stratigraphic section of a colluvial fan at Vaise (suburb of Lyon; Bertran et al., 1998). The aggradation and the lateral expansion of the floodplains (exclusively for the Plateau Lyonnais area) favored the coupling of hillslopes and stream channels during this period. This process conducted individual channels and the anastomosed bed to improve their erosion efficiency on (i) footslope deposits and (ii) colluvial fans incorporating angular blocks.

The major change occurred during the 1950-1960s when watercourses probably began to contract into a single channel. Indeed, for the Chaudanne River, interviews with riverine property owners indicate that a small stream channel (about $1 \mathrm{~m}$ width and $50 \mathrm{~cm}$ depth) still existed at this time and that frequent overflows arose. This might explain the rounded shape of riverbanks developed with mostly sandy deposits trapped by grassland. This first stage of channel contraction could have been caused by the end of the LIA and a decrease of croplands and ploughlands (Fig. 3) that reduced hillslope erosion and thus sediment inputs to rivers. This trend accelerated during the second half of the twentieth century owing to the continuous decrease in cropland on the one hand and the increase of afforestation and urban areas on the other hand (Fig. 3). This tendency is confirmed by the disappearance of colluvial deposits since the second half of the twentieth century in the upper part of the stratigraphies except for that of the PrèsMouchettes, which is entirely composed of colluvium (Fig. 2). By the classical effect of retroaction, these new conditions weakened the lateral dynamics of stream beds that rendered rarer the reworking and the transport of colluvial deposits stored on floodplains or on footslopes. This trend is confirmed because at that time the stream channel was marked by a deep entrenchment and a great lateral enlargement (Grosprêtre, 2011; Preusser et al., 2011) making the frequency of overflows decrease along many reaches. Thus, supply of the coarsest sediments is now dominated by indirect inputs from bed and bank erosion of layers previously deposited from the sixteenth to nineteenth century (Fig. S2). 


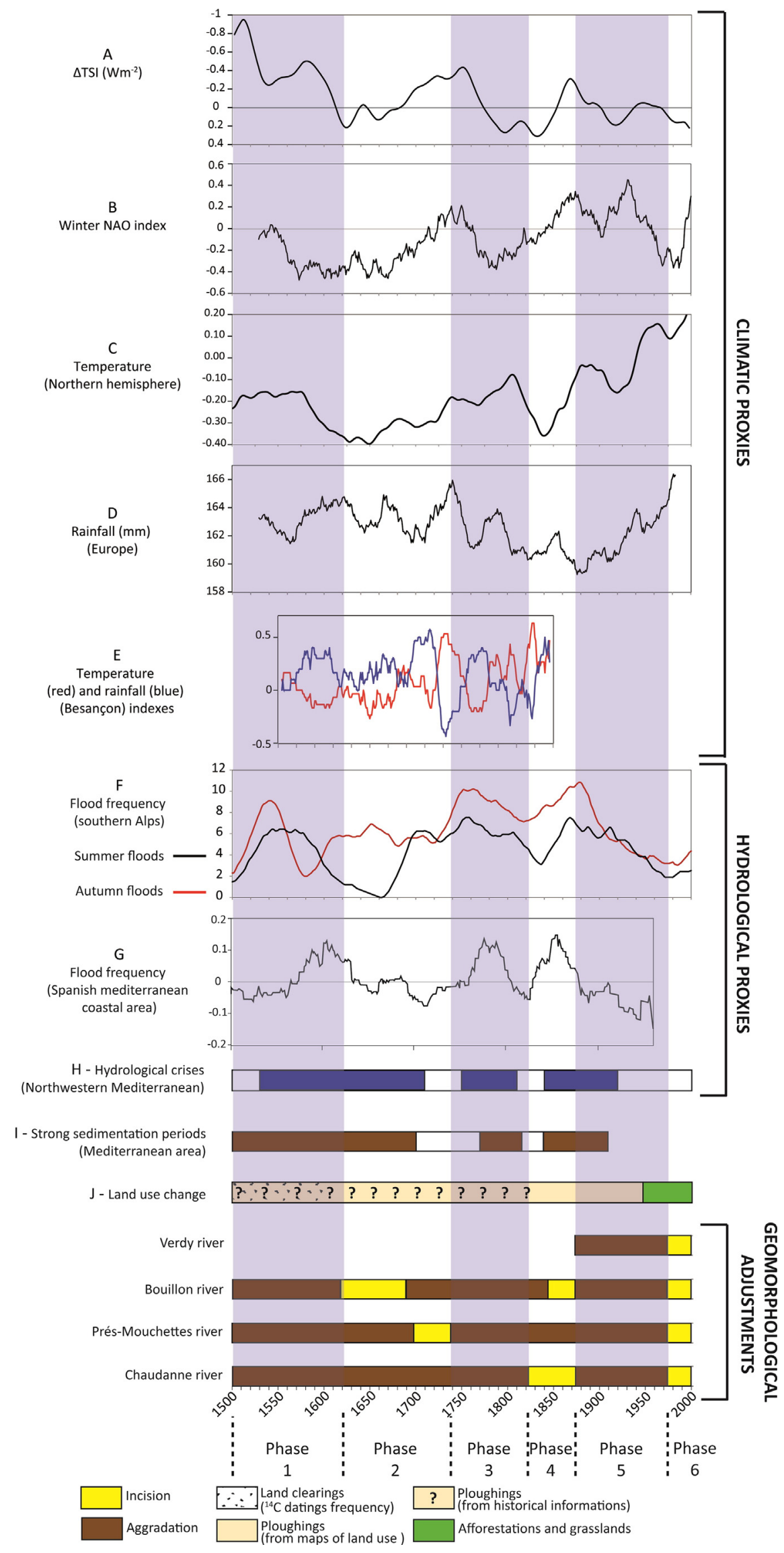


In this sedimentary cascade model, characterized by alternating phases of storage and removal (Figs. 5 and 6), the simultaneous or alternating combination of the multiple sedimentary sources arise under anthropogenic control. Climatic variations should not be underestimated though.

\subsection{Hydrogeomorphological adjustments to climate variability and land use changes}

Despite high sediment supply from hillslopes, the rhythm of aggradation appears discontinuous through time. Two incision phases occur between the sixteenth and nineteenth centuries (A.D. 1620-1740 and 1820-1870; Fig. 8), suggesting an internal secular rhythmicity within the LIA. We hypothesize that these incision phases might have been triggered by variations in the rainfall regime and, more precisely, by a decrease in the frequency of heavy rainfall events leading to a relative lowering of sediment supply from hillslopes. This hypothesis is supported by previous studies made in regional environments (Gob et al., 2008; Astrade et al., 2011). Fig. 8 compares the evolution (A.D. 15002000) of climatic and hydrologic proxies with geomorphic adjustments (aggradation vs. incision) of the four streams considered here and in other well-studied fluvial systems of the Mediterranean region. This figure shows that the LIA was marked by three periods of high fluvial activity and two periods of relative calm (Gob, 2005; Gob et al., 2008).

From A.D. 1500 to 1620 (first gray band, Fig. 8), the Bouillon, Chaudanne, and Près-Mouchettes valley bottoms recorded high sedimentation rates, as did several rivers of the Mediterranean area (Fig. 8I). Such sedimentation increase was also recorded in rivers of the southern Massif Central (Jacob, 2003; Gob et al., 2008), as well as of the western side of the Monts du Lyonnais. In this area, small alluvial plains of the Forez basin were filled with $<2-3 \mathrm{~m}$ of sandy-gravel sediments, in which are found fossilized wood pipes dating from the midfifteenth century (Cubizolle, 2009). Municipal archives of Lyon report that the second half of the sixteenth century was marked by a sharp intensive cooling and major flooding of the Rhône River (Municipal archives of Lyon, 2012). Similarly, historical studies of rivers flooding in the lower Rhône valley described a broad flood phase over the sixteenth century (Pichard, 1995; Pichard and Roucaute, 2014). Further and at a larger scale, this first period corresponds closely to a peak in flood frequency in the southern Alps (Fig. 8F) and Spanish Mediterranean coast (Fig. 8G) and to the first torrential crisis in the northwestern Mediterranean area (Fig. $8 \mathrm{H}$ ). These were generated by a decrease of the total solar irradiation ( $\triangle \mathrm{TSI}$, Fig. $8 \mathrm{~A}$ ) and the increasingly negative values of the winter NAO index (Fig. 8B), which led to a decrease of temperature and an increase of rainfall (Figs. 8C-E). This causal relationship between climatic evolution (cool and wetter conditions) and hydrological adjustments (more frequent floods) has been recently emphasized for the northwestern Mediterranean region during the Holocene (Benito et al., 2015a, b). Even though there is evidence for climatic deterioration at this time, it is important to emphasize that this first phase relating to the aggradation of the valley bottom was caused also by the intensive land use suggested by the greatest frequency of radiocarbon ages during this period (Figs. 4B and 8).

Bouillon and Prés-Mouchette valley bottoms lowered between A.D. 1620 and 1740 (first white band, Fig. 8). This incision phase is slightly early compared to the sedimentation and hydrological decrease in the Mediterranean area of A.D. $1700-1770$ or $1710-1750$, respectively (Figs. 8H, I). The Rhône River is not exempt from this general trend as it manifested a slowdown in activity during the first half of the seventeenth century and A.D. 1712-1740 (Pichard 1995; Pichard and Roucaute, 2014). This decline in fluvial activity seems to be related to the first multidecennial phase of droughts during the second half of the seventeenth and early eighteenth centuries that occurred in most of the Mediterranean's western basins (Carozza et al., 2014). Climatic fluctuations seem to be the main control factor influencing the decrease in flood frequency along the Spanish Mediterranean coast and southern Alps (at least for summer floods), the timing of which is rather well centered on our recorded incision phase (A.D. 1620-1740; Figs. 8F and G). In the same way, hemispheric-scale parameters of the temperature and the winter NAO started to increase continuously early in phase two. However, both values remained slightly below their phase one averages until the end of phase two. During the first part of phase two, TSI values are positive; whereas during the second part they shift toward negative values (Fig. 8A). It is relatively difficult to assess precisely the impact of land use on the vertical dynamics of the valley bottoms during phase two because only historical textual information is available (De Farcy, 1950; Lorcin and Houssel, 2008). According to it, plowing activities would have been intense during this period, consequently ensuring a good connectivity between slopes and riverbeds. Aggradation did not occur, however. Instead, incision took place, probably because of the insufficient runoff related to the decrease in flood frequency required to ensure the transport of sediments toward the valley bottoms (Bravard, 2002).

The following phase three extended from A.D. 1740 to 1820 . It is a new period of aggradation of the valley bottoms in the western area of Lyon (second gray band, Fig. 8I). It is globally coeval with a strong sedimentation period in the Mediterranean area, a torrential crisis in the northwestern Mediterranean (Gob, 2005; Gob et al., 2008), and to higher flood frequencies in the southern Alps, Spanish Mediterranean coast, and more largely in the Mediterranean (Benito et al., 2015a,b). These hydrologic and geomorphological evolutions appear to result from climatic deterioration at a regional scale as evidenced by rainfall and temperature recorded in Besançon, some $200 \mathrm{~km}$ north-northeast of Lyon (Fig. 8E). But at the larger scale, most climatic proxies show a different trend: the overall decline of average European rainfall and the increase of $\triangle$ TSI and northern hemisphere temperature. Only the winter NAO index follows a trend consistent with climatic deterioration. Moreover, as we noted above, from the end of the Middle Ages to the nineteenth century, there was strong human pressure on land use, which would also explain this aggradation phase.

A new phase of incision occurred in the Chaudanne streambed in the mid-nineteenth century roughly between A.D. 1820 and 1870. More precisely, Preusser et al. (2011) argued the existence of two shortlived phases of incision during this period. These are separated by a subsequent aggradational phase (unknown age). The second incision reached a lower level $(310 \mathrm{~cm})$ than the first incision $(240 \mathrm{~cm})$. The first incision is directly followed by deposition in an undercut area of the bank, while the second incision was characterized by a narrower channel and thus preservation of the previously incised and filled section. As explained before, land use maps suggest no significant change during this period (Fig. 3), but a peak in agriculture occurred around 1860 in the Yzeron valley, followed by a decrease of vineyards and cropland (De Farcy, 1950). During this period, rainfall in Europe decreased to its lowest level since A.D. 1500 (Fig. 8D). According to several studies, the period A.D. $1820-1840$ is also characterized by severe droughts and a low frequency of high rainfall events (Bravard, 2000; Jacob-Rousseau and Astrade, 2010, 2014; Astrade et al., 2011). Thus the incision of the Chaudanne streambed could have been triggered

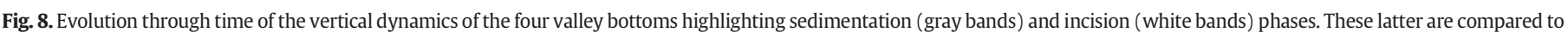

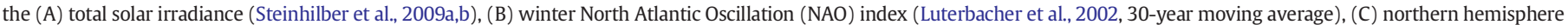

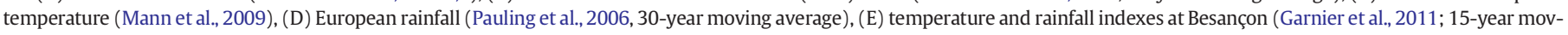

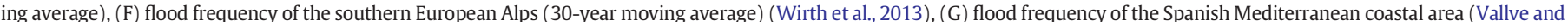

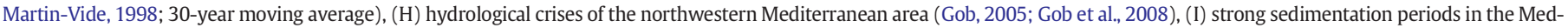

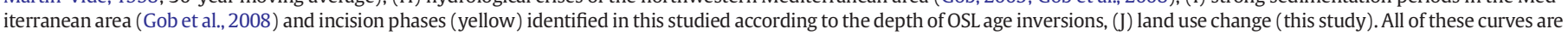
produced from annual averages, excluding curves B and F. (For interpretation of the references to color in this figure legend, the reader is referred to the web version of this article.) 
by a decrease in sediment supply from hillslopes, favored by soil stability despite intensive agriculture (plowing). Such developmental processes are reported in some prealpine catchments of the Rhône's tributaries (Bravard, 2000). The low flood frequency in different parts of western European (Figs. 8F and G) is coeval with the shifting conditions recorded also in palaeoflood archives of Lake Blanc in the French Alps (Wilhelm et al., 2013). Finally, we believe that despite the sediment availability related to the significant ploughings at this period, runoff was not sufficient to ensure the transport of sediments toward the valley bottoms caused by the decrease in flood frequency, unlike the previous period (phase 3 ). Such inhibition of sediment inputs in river beds from the slopes, following a rainfall deficit, was observed in the eastern Diois (French Southern Alps) during the first part of the nineteenth century (Bravard, 2002). As explained above, climatic conditions seem to control this trend. Winter NAO increased throughout phase four, and $\triangle T$ TSI reached its highest level early in this period then decreased rapidly after A.D. 1840 (Figs. 8A and B).

The OSL dating is not precise enough to determine exactly the timing of this phase four that ended earlier in the upper Ardèche (Jacob, 2003), southern Alps (Descroix and Gautier, 2002; Astrade et al., 2011), and in the Cévennes (Massif Central, France; Astrade et al., 2011). This was also the case for the Mediterranean area where many rivers recorded a decrease of their hydrological and sedimentary activity until A.D. 1840 (Fig. 8H and I).

The same time offset is observed in phase five with a return to high sedimentation rates about 30 years earlier in the Mediterranean area (around A.D. 1840) than in our studied watershed (around A.D. 1870). However, in the Cévennes, Jacob-Rousseau and Astrade (2014) reported high sediment delivery levels more synchronous with our chronology (since A.D. 1855-1870) that contributed to increased lateral mobility of riverbeds. In our basins, this new phase of sedimentary accumulation is not owing to climatic degradation because the end of the LIA is commonly dated to around the 1860s (Bravard, 1989; Labalette, 2009), and all indicators point toward a reversion to more clement climatic conditions (TSI, NAO, temperature, flood frequency). Consequently, land use could be a key to understanding this aggradation of valley floors. Figs. 3 and 8 clearly show that ploughlands and grasslands continued to be widespread up to A.D. 1914 in the four studied subcatchments. As discussed above, the major shift occurred between A.D. 1914 and 1970 when afforestation increased significantly (Figs. 3 and 8). While detailed land use evolution during this period is not known for the subcatchment scale, it seems that at the Yzeron's watershed scale, ploughlands and grasslands declined greatly from A.D. 1929 and 1970, respectively (Grosprêtre, 2011). Such aggradation of valley bottoms until the twentieth century is not an exception; for example, JacobRousseau and Astrade (2014) listed detrital inputs to the valley bottoms up to the first half of the twentieth century in the Cevennes (France).

\subsection{Seasonal variability of rainfall and geomorphological adjustments}

There are no local meteorological series that would document the monthly evolution of rainfall before the end of the nineteenth century. However, from studies carried out in neighboring areas, we provide some assumptions about the role of rainfall seasonal variability on sediment transfer in the small studied watersheds. As mentioned above, the Lyon region is characterized by a semicontinental climate, with pronounced Mediterranean and oceanic influences. The average monthly rainfall is largest in autumn (September to November) and spring (April-May). Nevertheless, the most sustained rains occur more than $70 \%$ of the time in summer, from July to September (Comby, 1998; Lecourieux, 1999). Given the intensity of precipitation, storm events have the highest morphogenic efficiency on the slopes as well as in the valley bottoms. However, several studies conducted during the last 15 years on basins from the middle Rhône valley, the western Alps, and the eastern Massif Central have highlighted quite significant variations in annual rainfall distribution and intensity (Bravard, 2000;
Descroix and Gautier, 2002; Jacob-Rousseau and Astrade, 2010; Astrade et al., 2011; Jacob-Rousseau and Astrade, 2014).

When comparing the vertical dynamics of the valley bottoms studied here (gray and white bands, Fig. 8) with the evolution of alpine floods (Fig. 8F), we observe that aggrading phases (phases one, three, five; Fig. 8) are perfectly centered on the maxima of the autumn floods, while the incision periods coincide with the minima of the summer floods (phases two, four, six; Fig. 8). The influence of intra-annual rainfall variability on hydrogeomorphological adjustments has also been demonstrated in the southern Alps and the Cévennes, where incision during the early nineteenth century occurred during a more pronounced rainfall deficit in September and October (the most important months for rainfall and river activity in this Mediterranean area) (Jacob-Rousseau and Astrade, 2010, 2014; Astrade et al., 2011). In addition, the same authors showed that during the 1850-1860s an important sediment discharge occurred during a period of unusually heavy rain in summer and autumn. These studies also suggest consideration of the role of the variability in atmospheric circulation. In the case of the Lyon area, the rainfall events can be classified into two main categories: firstly, the Atlantic disturbances related to the westerlies; and secondly, the Mediterranean rainfalls coming from the lower Rhône Valley (N-S exchanges). The latter produce more thunderstorms (Paturel, 1991). Bravard (2000), Descroix and Gautier (2002), and Astrade et al. (2011) also envisaged that one of the causes of the decrease in flood frequency could be the switch from a regime of Mediterranean summer storms to one of long and less intense rainfalls produced by westerly storm fronts coming from the Atlantic ocean during autumn and winter. This interpretation could be valid in the Lyon region given the origin of air masses.

Nevertheless, one should not underestimate the level of influence that the surface conditions of the basin have over the nature of geomorphic phenomena related to rainfall. Under the current conditions, with the absence of surfaces likely to provide a sediment load from the slopes, southern heavy rainfalls will promote river incision, as has been observed in November 2008. It was during this event that the trunks at the base of the Chaudanne section were excavated. This highlights the influence of Mediterranean climate on the Lyon region. The Mediterranean hydroclimatic events, whose intensity and frequency may vary over longer times, could be a very important driver of the vertical dynamics of the Lyon region's valley bottoms, particularly in the development of incision phases.

\section{Conclusions}

The OSL dating has shown a high potential to explain the recent sedimentation history of valley bottoms in small watersheds of the Yzeron basin (Rhône valley, France). These ages have revealed the complex history of the LIA's internal rhythms through several phases of aggradation-incision. Indeed, while the assemblage of radiocarbon dates is influenced significantly by ancient practices of land clearing by fires, thus confirming the limits of this method for dating developmental processes in such sedimentary environments, OSL ages reflect aggradation phases at valley bottoms and also, in some cases, incision phases of stream channels. This is an important issue in the case of small headwater streams, where underbank (and under-roots) scouring can play a relatively important role and explain OSL age-depth inversions.

Since A.D. 1500, these valley bottoms have undergone three cycles of aggradation-incision wherein two phases of low fluvial activity occurred (A.D. 1620-1740; 1820-1870). The impact of human activity was identified by the frequency of radiocarbon ages (first period) and the intense ploughings (third period). Nevertheless, the main controlling factor of the vertical dynamics of the valley bottoms seems to be the hydroclimatic variability of the LIA, exacerbated by land use conditions. This complexity is from the high sensitivity of such small basins to climate variations and different kinds of land use changes. Regarding 
river management, it appears illusory to target the stability of the longitudinal profiles of Yzeron basin streams (in the present and/or the future) precisely in the measure that incision is likely to expand in the whole basin, even in subcatchments not affected by urbanization. Nevertheless, it seems important to mitigate UI and/or CSO induced by urbanization, because it increases significantly the volume of sediments removed by incisions in comparison with rural areas (Grosprêtre, 2011). River bed stabilization techniques should only be used in case local issues like destabilization risk houses or roads by incised channels.

The use of the CM technique allowed us to assess the main sediment sources (runoff over plowed lands, reworked materials from colluvial fans, hillslope foots, river banks and valley bottom deposits, and lateral erosion of the outcropping bedrock) in the Yzeron's subcatchments. Based on these interpretations, we proposed modeling long-term transport of the bedload as a sedimentary cascade, with alternating periods of storage (aggradation) and periods of incision.

The next step of our investigations in this area will be extensive field work, collecting cores along the transverse and longitudinal dimensions of the floodplains of the Yzeron catchment. By this, we hope to improve reconstruction of the fluvial architecture of the floodplain deposits as has been previously done in other basins (Walter and Merritts, 2008; Lespez et al., 2011).

Supplementary data to this article can be found online at http://dx. doi.org/10.1016/j.geomorph.2016.01.010.

\section{Acknowledgments}

This study was funded by the Field Observatory for Urban Water Management (Observatoire de Terrain d'Hydrologie Urbaine, OTHU), the ANR (AVuPUR) (Assessing the Vulnerability of Peri-Urban Rivers) project, which was coordinated by Isabelle Braud, and the French ARTEMIS radiocarbon dating program (CNRS). Gamma spectrometry was carried out by Sönke Szidat, Departement für Chemie und Biochemie, Universtität Bern. Sarah Ivorra (UMR 5059 CNRS, Centre de BioArchéologie et d'Ecologie, Montpellier, France) kindly identified the tree trunks. Land use data were kindly provided by Marylise Cottet, Grégoire Privolt, Christine Jacqueminet, Kristell Michel, and Saïda Kermadi. Catherine Latour-Argant has tested the palynological potential of the Chaudanne site, which was unfortunately negative. We acknowledge Jean-Paul Bravard for helpful discussions concerning the palaeoenvironmental interpretation of the results, and his expertise on the field. Laine Clark-Balzan is thanked for her comments and language corrections. We also thank the editor Richard A. Marston, as well as the anonymous reviewer, for reviewing the manuscript; they provided very constructive comments that greatly contributed to manuscript improvements.

\section{References}

Acot, P., 2005. Histoire du climat. Perrin, Paris, France.

Allée, P., 2003. Dynamiques hydrosédimentaires actuelles et holocènes dans les systèmes fluviaux de moyenne montagne (Limousin, hautes Cévennes, Maures) (Mémoire d'Habilitation à Diriger des Recherches). Université de Limoges, Limoges.

Angot, A., 1883. Etude sur les vendanges en France, Annales du Bureau central météorologique de France.

Arnaud, F., Revel, M., Chapron, E., Desmet, M., Tribovillard, N., 2005. 7200 years of Rhône river flooding activity in Lake Le Bourget, France: a high-resolution sediment record of NW Alps hydrology. The Holocene 15, 420-428.

Arnaud-Fassetta, G., 2008. La géoarchéologie fluviale. EchoGéo 1-15.

Astrade, L., Jacob-Rousseau, N., Bravard, J.-P., Allignol, F., Simac, L., 2011. Detailed chronology of mid-altitude fluvial system response to changing climate and societies at the end of the Little Ice Age (Southwestern Alps and Cévennes, France). Geomorphology $133,100-116$

Auzet, A.-V., 1990. L'érosion des sols par l'eau dans les régions de grande culture: aspects agronomiques. Ministère de l'environnement, Neuilly-sur-Seine, France.

Auzet, V., 1987. L'érosion des sols cultivés en France sous l'action du ruissellement. Geo 96, 529-556.

Benito, G., Macklin, M.G., Zielhofer, C., Jones, A.F., Machado, M.J., 2015a. Holocene flooding and climate change in the Mediterranean. CATENA, Past Hydrological Extreme Events in a Changing Climate 130, 13-33.
Benito, G., Macklin, M.G., Panin, A., Rossato, S., Fontana, A., Jones, A.F., Machado, M.J., Matlakhova, E., Mozzi, P., Zielhofer, C., 2015b. Recurring flood distribution patterns related to short-term Holocene climatic variability. Scientific Reports 5, 1-8.

Berger, J.-F., 2011. Hydrological and post-depositional impacts on the distribution of Holocene archaeological sites: the case of the Holocene middle Rhône River basin, France. Geomorphology 129, 167-182.

Berger, J.-F., Delhon, C., Bonte, S., Thiebault, S., Peyric, D., Beeching, A., Vital, J., 2002. Paléodynamique fluviale, climat, action humaine et évolution des paysages du bassin versant de la Citelle (moyenne vallée du Rhône, Drôme) au cours de l'Atlantique ancien (8000-6000 BP) à partir de l'étude de la séquence alluviale d'EspelucheLalo. In: Bravard, J.-P., Magny, M. (Eds.), Les Fleuves Ont Une Histoire, PaléoEnvironnement Des Rivières et Des Lacs Français Depuis 15000 Ans, pp. 223-237 (Motz (Savoie)).

Berger, J.-F., Blanchemanche, P., Reynès, C., Sabatier, P., 2010. Dynamiques fluviales en basse vallée du Vidourle au cours des six derniers siècles. Quaternaire 21, 27-41.

Bertoncello, F., 2008. Histoire et modélisation des dynamiques socio-environnementales holocènes des paysages fluviaux de la Côte d'Azur. Bulletin du Musée d'Anthropologie préhistorique de Monaco, pp. 247-253.

Bertran, P., 2004. Soil erosion in small catchments of the quercy region (southwester France) during. The Holocene 14, 597-606.

Bertran, P., Texier, J.-P., 1997. Géoarchéologie des versants: les dépôts de pente. In: Bravard, J.-P., Presteau, M. (Eds.), Dynamique Du Paysage, Documents d'Archéologie En Rhône-Alpes, pp. 59-86 (Lyon).

Bertran, P., Fabre, L., Franc, O., Limondin-Lozouet, N., Thiébault, S., 1998. Évolution d'un versant au cours de l'Holocène à Vaise (France). Géog. Phys. Quatern. 52, 69-90.

Blaauw, M., 2010. Methods and code for "classical" age-modelling of radiocarbon sequences. Quat. Geochronol. 5, 512-518.

Bravard, J.-P., 1985. Le méandre de la Malourdie sur le Rhône court-circuité de Chautagne (Savoie), dynamique fluviale appliquée à l'écologie. Bulletin rhodanien de géomorphologie 3-16.

Bravard, J.-P., 1989. La métamorphose des rivières des alpes françaises à la fin du MoyenÂge et à l'époque moderne. Bulletin de la Société Géographique de Liège. 25, pp. $145-157$

Bravard, J.-P., 1993. Des versants aux cours d'eau. Les implications des fluctuations paléohydrologiques à l'époque médiévale. In: Colardelle, M. (Ed.), L'homme et La Nature Au Moyen Âge. Presented at the Actes du Ve congrès international d'archéologie médiévale, pp. 171-179 (Grenoble, Errance).

Bravard, J.-P., 2000. Le comportement hydromorphologique des cours d'eau au Petit Age Glaciaire dans les Alpes françaises et sur leur piedmont, in: 25e Journées Scientifiques de GFHN. Meudon, France. pp. 105-110.

Bravard, J.-P., 2002. Les réponses des systèmes fluviaux à une réduction des flux d'eau et de sédiments sous l'effet du reboisement en montagne. Presented at the 168ème session du Comité scientifique et technique de la Société Hydrotechnique de France, colloque forêts et eau, La houille blanche, Nancy. p. 8.

Bravard, J.-P., Peiry, J.-L., 1999. The CM pattern as a tool for the classification of alluvial suites and floodplains along the river continuum. In: S.B., M., J., A. (Eds.), Floodplains: Interdisciplinary Approaches, Geological Society Special Publication, pp. 259-268 (London).

Bravard, J.-P., Petit, F., 2000. Les cours d'eau dynamique du système fluvial, Armand Colin. ed. (Paris).

Bravard, J.-P., Salvador, P.-G., 2009. Géoarchéologie des plaines alluviales. La Géologie : Les Sciences de La Terre Appliquées à L'archéologie, Archéologiques, pp. 91-126 (Paris).

Bravard, J.-P., Goichot, M., Tronchère, H., 2014. An assessment of sediment-transport processes in the Lower Mekong River based on deposit grain sizes, the CM technique and flow-energy data. Geomorphology 207, 174-189.

Brown, A.G., 1997. Alluvial Geoarchaeology: Floodplain Archaeology and Environmental Change, Cambridge Manuals in Archaeology. Cambridge university press, Cambridge.

Carcaillet, C., Talon, B., 1996. Aspects taphonomiques de la stratigraphie et de la datation de charbons de bois dans les sols : exemple de quelques sols des Alpes. Géog. Phys. Quatern. 50, 233-244.

Carozza, J.-M., Devillers, B., Marriner, N., Morhange, C., 2014. “Introduction”. Le petit âge de glace en Méditerranée. Méditerranée 122, 3-9.

Chazal, P., Dumont, R., Aurion, B., 1955. La Nécessaire révolution fourragère et l'expérience lyonnaise. Le journal de la France agricole, Paris.

Chocat, B., 1997. Le rôle possible de l'urbanisation dans l'aggravation du risque d'inondation : l'exemple de l'Yzeron (Lyon). Revue de Géographie de Lyon 72, 273-280.

Chrzazvez, J., Théry-Parisot, I., Fiorucci, G., Terral, J.-F., Thibaut, B., 2014. Impact of postdepositional processes on charcoal fragmentation and archaeobotanical implications: experimental approach combining charcoal analysis and biomechanics. J. Archaeol. Sci. 44, 30-42.

Chuine, I., Yiou, P., Viovy, N., Seguin, B., Daux, V., Ladurie, E.L.R., 2004. Historical phenology: grape ripening as a past climate indicator. Nature 432, 289-290.

Clement, R.M., Horn, S.P., 2001. Pre-Columbian land-use history in Costa Rica: a 3000-year record of forest clearance, agriculture and fires from Laguna Zoncho. The Holocene $11,419-426$.

Comby, J., 1998. Les paroxysmes pluviométriques dans le couloir Rhodanien (Thèse de doctorat en Géographie et Aménagement). Université Jean Moulin Lyon III.

Cottet, M., 2005. Evolution de l'occupation du sol dans le bassin versant de l'Yzeron au 20e siècle: premiers éléments pour un diagnostic hydrologique.

Cubizolle, H., 2009. Paléo-environnements, Collection U. Géographie. A. Colin, Paris, France.

Daux, V., 2012. Les variations de températures printano-estivales dans le Bassin parisien depuis 1484. In: Berger, J.-F. (Ed.), Des Climats et Des Hommes, La Découverte/ Inrap, pp. 357-368 (Paris)

De Farcy, H., 1950. Paysans du Lyonnais, la vie agricole dans la vallée de l'Yzeron, Mémoires et Documents-Institut des Etudes Rhodaniennes. Audin, Lyon. 
Dearing, J.A., 1999. Environmental Magnetic Susceptibility. Using the Bartington MS2 System. Chi Publishing 32, 54.

Dearing, J.A., Hay, K.L., Baban, S.M.J., Huddleston, A.S., Wellington, E.M.H., Loveland, P.J., 1996. Magnetic susceptibility of soil: an evaluation of conflicting theories using a national data set. Geophys. J. Int. 127, 728-734.

Delile, H., 2014. Signatures des paléo-pollutions et des paléoenvironnements dans les archives sédimentaires des ports antiques de Rome et d'Éphèse (Doctorat de géographie/géoarchéologie). Université Lumière Lyon 2, Lyon.

Delile, H., Mazzini, I., Blichert-Toft, J., Goiran, J.-P., Arnaud-Godet, F., Salomon, F., Albarède, F., 2014. Geochemical investigation of a sediment core from the Trajan basin at Portus, the harbor of ancient Rome. Quat. Sci. Rev. 87, 34-45.

Delile, H., Abichou, A., Gadhoum, A., Goiran, J.-P., Pleuger, E., Monchambert, J.-P., Wilson, A., Fentress, E., Quinn, J., ben Jerbania, I., Ghozzi, F., 2015a. The geoarchaeology of Utica (Tunisia): the palaeo-geography of the Mejerda delta and hypotheses concerning the location of the ancient harbour. Geoarchaeology 4, 291-306.

Delile, H., Blichert-Toft, J., Goiran, J.-P., Stock, F., Arnaud-Godet, F., Bravard, J.-P., Brückner, H., Albarède, F., 2015b. Demise of a harbor: a geochemical chronicle from Ephesus. J. Archaeol. Sci. 53, 202-213.

Descroix, L., Gautier, E., 2002. Water erosion in the southern French alps: climatic and human mechanisms. Catena 50, 53-85.

Douguedroit, A., 1979. Les Paysages forestiers de Haute-Provence et des Alpes-Maritimes. Edisud, Aix-en-Provence, France.

Duby, G., 1954. La révolution agricole médiévale. Revue de géographie de Lyon 29, 361-366.

Dufour, M.L., 1870. Notes sur le problème de la variation du climat, Bulletin de la société Vaudoise des sciences naturelles.

Franc, O., 2005. Reconstitution paléo-environnementale à partir du contexte géomorphologique de quatre sites archéologiques de la plaine de l'Est lyonnais (Rhône, France). Quaternaire 16, 95-105.

Fuchs, M., Lang, A., 2009. Luminescence dating of hillslope deposits - a review. Geomorphology, Luminescence Dating in Geomorphology 109, 17-26.

Garnier, E., Daux, V., Yiou, P., Cortázar-Atauri, I.G.d., 2011. Grapevine harvest dates in Besançon (France) between 1525 and 1847: social outcomes or climatic evidence? Clim. Chang. 104, 703-727.

Garnot, B., 1998. Les campagnes en France aux XVIe, XVIIe et XVIIIe siècles, Synthèse et histoire. Gap, Ophrys.

Gautier, E., 1992. Recherches sur la morphologie et la dynamique fluviale dans le bassin du Büech (Alpes du Sud). Université Paris 10, France.

Gob, F., 2005. La lichénométrie appliquée à l'étude de rivières en gorge en milieu méditerranéen : Caractérisation de leurs paramètres dynamiques et de leur évolution géomorphologique durant le Petit Age Glaciaire. Université de Liège.

Gob, F., Jacob, N., Bravard, J.-P., Petit, F., 2008. The value of lichenometry and historical archives in assessing the incision of submediterranean rivers from the Little Ice Age in the Ardèche and upper Loire (France). Geomorphology 94, 170-183.

Grosprêtre, L., 2011. Etude et gestion des impacts hydrogéomorphologiques de la périurbanisation. L'exemple du bassin de l'Yzeron dans l'Ouest lyonnais (Thèse de Doctorat). Université Lumière Lyon 2, Lyon.

Grove, J.M., 1988. The Little Ice Age. Methuen, London.

Horn, S.P., Sanford, R.L.J., 1998. Ancient fires and fields: reconstructing the long-term biotic history of the Las Cruces area. Amigos Newsletter 50, 12-15.

Houssel, J.-P., 2006. Des débuts de la révolution fourragère dans le lyonnais à la modernisation en petite culture. Géocarrefour 81, 319-326.

Huckleberry, G., Rittenour, T., 2014. Combining radiocarbon and single-grain optically stimulated luminescence methods to accurately date pre-ceramic irrigation canals, Tucson, Arizona. J. Archaeol. Sci. 41, 156-170.

Jacob, N., 2003. Les vallées en gorges de la Cévenne vivaraise. Montagne de sable et château d'eau. University of Paris IV - Sorbonne, Paris, France.

Jacob-Rousseau, N., Astrade, L., 2010. Sécheresses et pénuries d'eau dans la France méridionale entre 1815 et 1840. La Houille Blanche 43-50.

Jacob-Rousseau, N., Astrade, L., 2014. Phénomènes torrentiels et transferts sédimentaires autour du massif du Tanargue, de l'âge du fer au petit âge de glace (PAG) (Cévennes vivaraises, France). Méditerranée 63-79.

Jacqueminet, C., Kermadi, S., Michel, K., Béal, D., Gagnage, M., Branger, F., Jankowfsky, S., Braud, I., 2013. Land cover mapping using aerial and VHR satellite images for distributed hydrological modelling of periurban catchments: Application to the Yzeron catchment (Lyon, France). Journal of Hydrology, Hydrology of Peri-urban Catchments: Processes and Modelling 485, 68-83.

Jorda, M., 1980. Morphogenèse et évolution des paysages dans les Alpes de Haute- Provence depuis le Tardiglaciaire. Facteurs naturels et facteurs anthropiques. Bulletin de l'Association de Géographes Français. 472, pp. 295-304.

Labalette, F., 2009. Les terribles ravages du "grand hiver". Historia 46.

Lamb, H.H., 1977. Climate: Present, Past and Future. Methuen, London.

Lang, A., Hönscheidt, S., 1999. Age and source of colluvial sediments at Vaihingen-Enz, Germany. Catena 38, 89-107.

Lang, A., Moya, J., Corominas, J., Schrott, L., Dikau, R., 1999. Classic and new dating methods for assessing the temporal occurrence of mass movements. Geomorphology 30, 33-52.

Le Roy Ladurie, E., 1967. Histoire du climat depuis l'An mil. Flammarion, Paris, France.

Lecourieux, O., 1999. Répartition spatio-temporelle des précipitations du Grand Lyon.

Lespez, L., Le Drezen, Y., Aline, G., Rasse, M., Eichhorn, B., Ozainne, S., Ballouche, A., Neumann, K., Huysecom, E., 2011. High-resolution fluvial records of Holocene environmental changes in the Sahel: the Yamé River at Ounjougou (Mali, West-Africa). Quat. Sci. Rev. 30, 737-756.

Lespez, L., Viel, V., Rollet, A.J., Delahaye, D., 2015. The anthropogenic nature of present-day low energy rivers in western France and implications for current restoration projects. Geomorphology, Emerging Geomorphic Approaches to Guide River Management Practices 251, 64-76.
Lorcin, M.-T., 1974. Les campagnes de la région lyonnaise aux XIVe et XVe siècles. Université Lumière Lyon 2, Lyon.

Lorcin, M.-T., Houssel, J.-P., 2008. Le plateau lyonnais : coteaux et vallons. Éd. Bellier, Lyon.

Luterbacher, J., Xoplaki, E., Dietrich, D., Jones, P.D., Davies, T.D., Portis, D., Gonzalez-Rouco, J.F., von Storch, H., Gyalistras, D., Casty, C., Wanner, H., 2002. Extending North Atlantic oscillation reconstructions back to 1500. Atmosph. Sci. Lett. 2, 114-124.

Macé, S., Vérot-Bourrély, A., Bravard, J.-P., 1991. Genèse et fonctionnement holocène de la plaine alluviale du Rhône à Lyon. Archéologie et Environnement Des Milieux Aquatiques. Presented at the Actes du 115ème colloque National des Sociétés Savantes, Chambéry, 1991. Editions du CTHS, Paris, pp. 17-31.

Macklin, M.G., Lewin, J., 2003. River sediments, great floods and centennial-scale Holocene climate change. J. Quat. Sci. 18, 101-105.

Macklin, M.G., Passmore, D.G., Stevenson, A.C., Davis, B.A., Benavente, J.A., 1994. Response of rivers and lakes to Holocene environmental change in the Alcaniz Region, Teruel, Northweast Spain. In: Millington, A.C., Pye, K. (Eds.), Environmental Change in Drylands: Biogeographical and Geomorphological Perspectives, pp. 113-130 (Chichester).

Macklin, M.G., Lewin, J., Woodward, J.C., 1995. Quaternary fluvial systems in the Mediterranean basin. In: Lewin, J., Macklin, M.G., Woodward, J.C. (Eds.), Mediterranean Quaternary River Environments, pp. 1-25 (Rotterdam).

Macklin, M.G., Lewin, J., Woodward, J.C., 2012. The fluvial record of climate change. Philosophical Transactions of the Royal Society of London A: Mathematical, Physical and Engineering Sciences 370, 2143-2172.

Mandier, P., 1984. Le relief de la vallée du Rhône au tertiaire et au quaternaire - Essai de synthèse paléogéographique (Thèse d'État). Université Lyon 2, Lyon.

Mann, M.E., Zhang, Z., Rutherford, S., Bradley, R.S., Hughes, M.K., Shindell, D., Ammann, C., Faluvegi, G., Ni, F., 2009. Global signatures and dynamical origins of the little ice age and medieval climate anomaly. Science 326, 1256-1260.

Meier, N., Rutishauser, T., Pfister, C., Wanner, H., Luterbacher, J., 2007. Grape harvest dates as a proxy for Swiss April to August temperature reconstructions back to A.D. 1480. Geophys. Res. Lett. 34, 1-6.

Miramont, C., Guilbert, X., 1997. Variations historiques de la fréquence des crues et de la morphogenèse fluviale en Moyenne Durance. Géomorphologie : Relief, Processus, Environnement 325-338.

Miras, Y., Laggoun-Défarge, F., Guenet, P., Richard, H., 2004. Multi-disciplinary approach to changes in agro-pastoral activities since the Sub-Boreal in the surroundings of the "narse d'Espinasse" (Puy de Dôme, French Massif Central). Veget. Hist. Archaeobot. 13, 91-103.

Monna, F., Petit, C., Guillaumet, J.-P., Jouffroy-Bapicot, I., Richard, H., Tamas, C.G., Cauuet, B., Dominik, J., Losno, R., 2005. Du plomb chez les gaulois du Morvan. UB Sciences 100-104.

Municipal Archives of Lyon, 2012. Climat, à nos risques et périls: Les Lyonnais face aux caprices du climat, depuis le Moyen Âge. Archives municipales de Lyon, Lyon, France.

Murray, A., Wintle, A., 2000. Luminescence dating of quartz using an improved singlealiquot regenerative-dose protocol. Radiat. Meas. 33, 57-73.

Navratil, O., Breil, P., Schmitt, L., Grosprêtre, L., Albert, M.B., 2013. Hydrogeomorphic adjustments of stream channels disturbed by urban runoff (Yzeron River basin France). J. Hydrol. 485, 24-36.

Neboit, R., 1983. L'homme et l'érosion: l'érosion des sols dans le monde. Presses Universitaires, Clermont-Ferrand, France.

Notebaert, B., Verstraeten, G., Houbrechts, G., Petit, F., 2013. Holocene floodplain deposition and scale effects in a typical European upland catchment: a case study from the Amblève catchment, Ardennes (Belgium). The Holocene 23, 1184-1197.

Notebaert, B., Berger, J.-F., Brochier, J.L., 2014. Characterization and quantification of Holocene colluvial and alluvial sediments in the Valdaine Region (southern France). The Holocene 1-16.

Nussbaumer, S.U., Steiner, D., Zumbühl, H.J., 2012. Réseau neuronal et fluctuations des glaciers dans les Alpes occidentales. In: Berger, J.-F. (Ed.), Des Climats et Des Hommes, pp. 391-403 (Paris).

Passega, R., 1957. Texture as characteristic of clastic deposition. American Association of Petroleum Geologists 41, 1952-1984.

Paturel, J.-E., 1991. Etude des phénomènes pluvieux à une échelle fine. (Thèse Doctorat) INSA de Lyon, France.

Pauling, A., Luterbacher, J., Casty, C., Wanner, H., 2006. Five hundred years of gridded high-resolution precipitation reconstructions over Europe and the connection to large-scale circulation. Clim. Dyn. 26, 387-405.

Pichard, G., 1995. Les crues sur le bas Rhône de 1500 à nos jours. Pour une histoire hydroclimatique. Méditerranée 105-116.

Pichard, G., Roucaute, E., 2014. Pluies et crues en bas Rhône et caractérisation du petit âge de glace (PAG). Méditerranée 31-42.

Prescott, J., Hutton, J., 1994. Cosmic ray contributions to dose rates for luminescence and ESR dating: large depths and long term variations. Radiat. Meas. 23, 497-500.

Preusser, F., Degering, D., 2007. Luminescence dating of the Niederweningen mammoth site, Switzerland. Quat. Int. 164-165, 106-112.

Preusser, F., Kasper, H.U., 2001. Comparison of dose rate determination using highresolution gamma spectrometry and inductively coupled plasma-mass spectrometry. Ancient TL 19, 17-21.

Preusser, F., Blei, A., Graf, H., Schlüchter, C., 2007. Luminescence dating of Würmian (Weichselian) proglacial sediments from Switzerland: methodological aspects and stratigraphical Conclusions. Boreas 36, 130-142.

Preusser, F., Schmitt, L., Delile, H., Grosprêtre, L., 2011. Optically Stimulated Luminescence (OSL) dating of the sedimentation history of the Yzeron Basin (Chaudanne subcatchment), Rhône Valley, France. Quaternaire 22, 73-83.

Privolt, G., 2009. Contribution à l'analyse de la mise en place des colluvions sur le bassin versant de l'Yzeron. Etude diachronique fine de l'occupation du sol depuis deux siècles, sur quatre sous-bassins de l'Yzeron: la Chaudanne, le Bouillon, le Verdy et le Prés Mouchettes. 
Privolt, G., 2010. Contribution à la reconstitution du paysage du plateau lyonnais au cours du XIXème siècle. Interrogation de l'apport des archives iconographiques et constitution d'un inventaire critique d'archives.

Rackham, O., 1986. The history of the countryside. The Classic History of Britain's Landscape, Flora and Fauna. Weidenfeld \& Nicolson, London.

Reimer, P., Bard, E., Bayliss, A., Beck, J.W., Blackwell, P.G., Ramsey, C.B., Buck, C.E., Cheng, H., Edwards, R.L., Friedrich, M., Grootes, P.M., Guilderson, T.P., Haflidason, H. Hajdas, I., Hatté, C., Heaton, T.J., Hoffmann, D.L., Hogg, A.G., Hughen, K.A., Kaiser, K.F., Kromer, B., Manning, S.W., Niu, M., Reimer, R.W., Richards, D.A., Scott, E.M. Southon, J.R., Staff, R.A., Turney, C.S.M., van der Plicht, J., 2013. IntCal13 and Marine13 radiocarbon age calibration curves $0-50,000$ years cal BP. Radiocarbon 55, 1869-1887.

Rubellin, M., 2009. Les Monts du Lyonnais au Moyen Âge. In: Houssel, J.-P. (Ed.), Les Monts Du Lyonnais, pp. 25-37 (Châtillon-sur-Chalaronne).

Rumsby, B.T., Macklin, M.G., 1996. River response to the last neoglacial (the "Little Ice Age") in northern, western and central Europe. Geol. Soc. Lond., Spec. Publ. 115, 217-233.

Salomon, P., Delile, H., Goiran, J.-P., Bravard, J.-P., Keay, S., 2012. The Canale di Comunicazione Traverso in Portus: the Roman sea harbour under river influence (Tiber delta, Italy). Géomorphologie : Relief, Processus, Environnement 75-90.

Schmitt, L., Maire, G., Humbert, J., 2001. La puissance fluviale : définition, intérêt et limites pour une typologie hydro-géomorphologique de rivières. Z. Geomorphol. 45, 201-224.

Schmitt, L., Valette, L., Valin, K., Piégay, H., Hallot, E., 2006. Proposition d'une méthode de typologie hydrogéomorphologique des cours d'eau et test sur un sous-bassin du Rhône (bassin de l'Yzeron). Mosella 29, 323-340.

Schmitt, L., Lafont, M., Trémolières, M., Jezequel, C., Vivier, A., Breil, P., Namour, P., Valin, K., Valette, L., 2011. Using hydro-geomorphological typologies in functional ecology: preliminary results in contrasted hydrosystems. Phys. Chem. Earth 36, 539-548.

Steinhilber, F., Beer, J., Fröhlich, C., 2009a. Total solar irradiance during the Holocene. Geophys. Res. Lett. 36, 1-5.

Steinhilber, F., Beer, J., Fröhlich, C., 2009b. Total solar irradiance during the Holocene. Geophys. Res. Lett. 36, 1-5.

Théry-Parisot, I., Chabal, L., Chrzavzez, J., 2010. Anthracology and taphonomy, from wood gathering to charcoal analysis. A review of the taphonomic processes modifying charcoal assemblages, in archaeological contexts. Palaeogeogr. Palaeoclimatol. Palaeoecol. 291, 142-153.

Vallve, M.B., Martin-Vide, J., 1998. Secular climatic oscillations as indicated by catastrophic floods in the Spanish Mediterranean Coastal Area (14th-19th centuries). Clim. Chang. 38, 473-491.

Vannière, B., Laggoun-Defarge, F., 2002. Première contribtution à l'étude des évolutions paléohydrologiques et à l'histoire des feux en Champagne berrichonne duran
l'Holocène. Le cas du "Marais du Grand-Chaumet" (Indre, France). In: Bravard, J.-P., Magny, M. (Eds.), Les Fleuves Ont Une Histoire, Paléo-Environnement Des Rivières et Des Lacs Français Depuis 15000 Ans, pp. 101-124 (Motz (Savoie)).

Vannière, B., Bossuet, G., Gauthier, E., 2000. Susceptibilité magnétique et indices polliniques, marqueurs de l'impact anthropique et de la dynamique fluviale dans la basse vallée du Doubs (Jura, France) entre le Ier et le VIIIe siècles après J.-C. Comptes Rendus de l'Académie des Sciences. Series IIA - Earth and Planetary Science 331, pp. 203-210.

Verhagen, P., Berger, J.-F., 2001. Predictive modelling of buried archaeological sites in the Tricastin-Valdain Region (Middle Rhône Valley, France). In: Stancic, Z., Veljanovic, T. (Eds.), CAA 2000: Computing Archaeology for Understanding the Past. British Archaeological Report International Series, pp. 219-231.

Walter, R.C., Merritts, D.J., 2008. Natural streams and the legacy of water-powered Mills. Science 319, 299-304.

Wilhelm, B. Arnaud, F, Sabatier, P., Crouzet, C., Brisset, E., Chaumillon, E., Disnar, J.-R, Guiter, F., Malet, E., Reyss, J.-L., Tachikawa, K., Bard, E., Delannoy, J.-J., 2012. 1400 years of extreme precipitation patterns over the Mediterranean French Alps and possible forcing mechanisms. Quat. Res. 78, 1-12.

Wilhelm, B., Arnaud, F., Sabatier, P., Magand, O., Chapron, E., Courp, T., Tachikawa, K., Fanget, B., Malet, E., Pignol, C., Bard, E., Delannoy, J.J., 2013. Palaeoflood activity and climate change over the last 1400 years recorded by lake sediments in the northwest European Alps. J. Quaternary Sci. 28, 189-199.

Wintle, A., Murray, A., 2006. A review of quartz optically stimulated luminescence characteristics and their relevance in single-aliquot regeneration dating protocols. Radiat. Meas. 41, 369-391.

Wirth, S.B., Gilli, A., Simonneau, A., Ariztegui, D., Vannière, B., Glur, L., Chapron, E., Magny, M., Anselmetti, F.S., 2013. A 2000 year long seasonal record of floods in the southern European Alps. Geophys. Res. Lett. 40, 4025-4029.

Wynn, T., Mostaghimi, S., 2006. The effects of vegetation and soil type on streambank erosion, Southwestern Virginia, Usa1. J. Am. Water Resour. Assoc. 42, 69-82.

Zaimes, G.N., Schultz, R.C., Isenhart, T.M., 2004. Stream bank erosion adjacent to riparian forest buffers, row-crop fields, and continuously-grazed pastures along Bear Creek in central Iowa. J. Soil Water Conserv. 59, 19-27.

Zander, A., Degering, D., Preusser, F., Kasper, H.U., Brückner, H., 2007. Optically stimulated luminescence dating of sublittoral and intertidal sediments from Dubai, UAE: radioactive disequilibria in the uranium decay series. Quat. Geochronol. 2, 123-128.

Zumbühl, H.J., Nussbaumer, S.U., 2012. Les glaciers des Alpes centrales et occidentales dans l'iconographie ancienne. In: Berger, J.-F. (Ed.), Des Climats et Des Hommes, pp. 379-389 (Paris) 